\title{
The oldest palaeoloricate mollusc (Cambrian Series 2, Stage 4; North Greenland) and its bearing on aculiferan evolution
}

John S. Peel

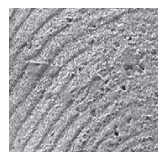

In the Aculifera-Conchifera model of molluscan evolution, spiculate aplacophorans and polyplacophorans with a dorsal series of shell plates are recognised as sister groups within the clade Aculifera, itself a sister group of the clade Conchifera that contains all other molluscs. While aculiferans and conchiferans had their common origin near the Precambrian-Cambrian boundary, the crown groups of most major molluscan classes are seen traditionally to have emerged in the latest Cambrian (Furongian)-Early Ordovician. Matthevia Walcott, 1885, from the latest Furongian-Early Ordovician of Laurentia, has been regarded almost universally as the oldest undoubted fossil chiton, a palaeoloricate. Palaeoloricates, however, are paraphyletic and Matthevia is variously interpreted as a time indicator for the origin of crown group Aculifera, within either the stem or crown groups of Aplacophora or Polyplacophora. The discovery of rare disarticulated plates from the early Cambrian (Cambrian Series 2, Stage 4) of North Greenland (Laurentia) extends the geological record of palaeoloricates by about $25 \mathrm{Ma}$. In bridging the gap between lower stem group aculiferans and the occurrence of Matthevia, the new finds offer the potential for a corresponding earlier origin of both aplacophorans and polyplacophorans within the aculiferan crown group. Head and intermediate plates are described from the Aftenstjernesø Formation and placed within a new taxon proposed as Qaleruaqia sodermanorum gen. et sp. nov. Key words: Mollusca, Aculifera, palaeoloricate, Cambrian Series 2, North Greenland, Laurentia.

Peel, J.S. 2020. The oldest palaeoloricate mollusc (Cambrian Series 2, Stage 4; North Greenland) and its bearing on aculiferan evolution. Bulletin of Geosciences 95(2), 127-144 (9 figures). Czech Geological Survey, Prague. ISSN 1214-1119. Manuscript received January 4, 2020; accepted in revised form May 11, 2020; published online May 30, 2020; issued May 30, 2020.

John S. Peel, Department of Earth Sciences (Palaeobiology), Uppsala University, Uppsala, Sweden; john.peel@pal.uu.se

Molluscs are one of the most diverse of extant invertebrate phyla with an extensive geological record reaching back to the Precambrian-Cambrian boundary (Budd \& Jensen 2007, Maloof et al. 2010, Wanninger \& Wollesen 2019). Most extant molluscan classes are traditionally recognised from around the late Cambrian (Furongian)Early Ordovician boundary or later (Runnegar \& Pojeta 1974, Yochelson 1978, Budd \& Jensen 2007, Vinther et al. 2012a, Vinther 2015) but older Cambrian strata yield a variety of extinct and often poorly understood groups that usually rest uncomfortably in phylogenetic schemes (Pojeta \& Runnegar 1976; Runnegar \& Pojeta 1985; Yu 1987; Missarzhevsky 1989; Qian \& Bengtson 1989; Peel 1991a; Gravestock et al. 2001; Steiner et al. 2007; Parkhaev 2008, 2019; Maloof et al. 2010; Parkhaev \& Demidenko 2010; Rozanov et al. 2010; Hou et al. 2017).

Spectacular rare finds from Lower Palaeozoic lagerstätten have generated considerable excitement amongst students of molluscan evolution on account of unexpected morphological features and exceptional preservation (Conway Morris \& Peel 1995; Sutton et al. 2001, 2012;
Caron et al. 2006; Conway Morris \& Caron 2007; Vinther et al. 2017). Foremost amongst these is the sluglike Halkieria evangelista Conway Morris \& Peel, 1995 from the early Cambrian (Cambrian Series 2, Stage 3) Sirius Passet Lagerstätte of North Greenland, with its chain mail armour of small pointed sclerites and much larger anterior and posterior plates (Conway Morris \& Peel 1995). To abuse a well-known English idiomatic expression, famously paraphrased by the English journalist Fonblanque (1837, p. 342), Halkieria is "a smooth round peg, in a sharp-cornered square hole" that can slip effortlessly into a variety of phylogenetic settings. Evolutionists disagree about its affinities despite this morphological facility and Halkieria has been placed in (and variously rejected from) the stem groups of molluscs, stem group aculiferan molluscs, a separate molluscan class, annelids, brachiopods and tommotiids (Peel 1991b, Conway Morris \& Peel 1995, Holmer et al. 2002, Eibye-Jacobsen 2004, Vinther \& Nielsen 2005, Conway Morris \& Caron 2007, Vinther 2014, Zhao et al. 2017, Vinther et al. 2017, Han et al. 2019); Vinther et al. (2017 supplementary material) gave a full list to date. 

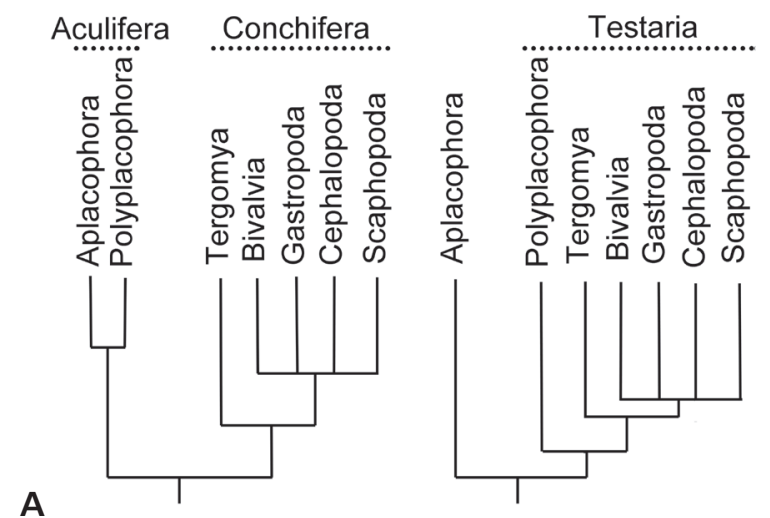

Figure 1. Models of molluscan evolution. - A - Aculifera-Conchifera model. $\cdot$ B - Testaria model in which aplacophorans are the sister group to all other molluscs.

Most recent discussions of molluscan evolution have concentrated on the Aculifera-Conchifera model (Fig. 1A) in which Aculifera (aplacophorans and polyplacophorans) form a sister group to other, conchiferan, molluscs (Sigwart \& Sutton 2007; Sutton \& Sigwart 2012; Sutton et al. 2012; Vinther et al. 2012a, b, 2017; Scherholz et al. 2013; Kocot et al. 2019, 2020; Wanninger \& Wollesen 2019). Vinther (2014) summarised the gradual integration of evidence from developmental biology and classical palaeontology that brought forward the hypothesis that aplacophorans and polyplacophorans shared a common ancestry. He credited Ivanov (1996) as the first to explicitly propose that aplacophorans may have been derived from a chiton-like mollusc with shell plates serially arranged along the dorsum (Scheltema \& Ivanov 2002, Scherholtz et al. 2013). Descriptions of Ordovician and Silurian specimens by Sutton et al. (2001, 2004, 2012), Cherns (1998a, b, 2004) and Sigwart \& Sutton (2007) have added remarkable support from the fossil record. Sigwart \& Sutton (2007) proposed that some Ordovician palaeoloricates, usually interpreted as primitive polyplacophorans (Smith 1960, Hoare \& Pojeta 2006, Pojeta et al. 2010), were probably stem group aplacophorans and this theme was strengthened with the description of the remarkable 7-plated Kulindroplax perissokomos Sutton, Briggs, Siveter, Siveter, \& Sigwart, 2012 from the Silurian of England.

Based on molecular phylogenetic analysis, Vinther et al. (2012a) concluded that crown group aculiferans (aplacophorans and polyplacophorans) arose during the Early Ordovician, although Kocot et al. (2020) suggested a slightly earlier separation, in the Furongian. Vinther et al. (2012a) suggested that late Cambrian (Furongian) palaeoloricates such as Matthevia Walcott, 1885 (Walcott 1885, 1886; Yochelson 1966; English 2002; Vendrasco \& Runnegar 2004) were upper stem group aculiferans derived from lower stem group aculiferans that include
Halkieria. Sutton et al. (2012) placed Matthevia within the aplacophoran crown group and Halkieria as a stem group mollusc.

Following the discovery of the exceptionally preserved Calvapilosa kroegeri Vinther, Parry, Briggs \& Van Roy, 2017 from the Fezouata Formation Lagerstätte (Early Ordovician) of Morocco, Vinther et al. (2017, fig. 4) placed Matthevia within the evolving aplacophoran line as a crown group or upper stem group aculiferan, at a higher level than the lower sachitids, including Halkieria and Calvapilosa, which they placed within the aculiferan stem rather than the stem group of Mollusca. While accepting Calvapilosa as an aculiferan, Zhao et al. (2017) were sceptical about accepting Halkieria as a mollusc.

Matthevia was originally described from the Furongian of New York (Walcott 1885, 1886; English 2002) but later recorded also from the Ordovician (Pojeta et al. 2005). As the hitherto oldest palaeoloricate, it holds a key position in discussions concerning the time of emergence of total group aplacophorans and polyplacophorans (Vendrasco \& Runnegar 2004, Pojeta et al. 2010). Thus, Vinther et al. (2012a) cited the absence of polyplacophorans and aplacophorans from the early and middle Cambrian as a problem for hypotheses that placed aplacophorans as a sister group to all other molluscs, the so-called Testaria hypothesis (Haszprunar 1996, 2000; Salvini-Plawen 2006; Fig. 1B), an absence that supports the notion that aplacophorans evolved from Early Ordovician palaeoloricates (stem group aculiferans). Following a somewhat chequered history of interpretation (Walcott 1885, 1886; Yochelson 1966; English 2002; Vendrasco \& Runnegar 2004), and despite being known only from disarticulated plates, a generally accepted picture has emerged of the nature of this serially plated mollusc. An excellent reconstruction as an 8-plated form by Brian Roach was presented by Vinther (2014, fig. 2) and Vinther et al. (2012a, fig. 4), although the question of eight plates, as in polyplacophorans, as conventionally assumed, or seven plates as in Kulindroplax is unresolved.

This paper describes Qaleruaqia sodermanorum gen. et $\mathrm{sp}$. nov. on the basis of rare isolated plates from the Aftenstjernesø Formation (Cambrian Series 2, Stage 4) in North Greenland (Fig. 2). The rare specimens of Qaleruaqia sodermanorum gen. et sp. nov. are compared to the unique articulated specimens of Halkieria evangelista that were collected only about $12 \mathrm{~km}$ to the north-east (Fig. 2). Head and intermediate plates are recognised in Qaleruaqia following comparison with Matthevia and other serially plated fossils. Qaleruaqia is interpreted as lying close to the basal node of the crown group Aculifera in the model of Vinther et al. (2017), as an upper stem group aculiferan or as an early member of either the stem group Aplacophora or the stem group Polyplacophora. Thus, Matthevia is no longer the oldest palaeoloricate and 

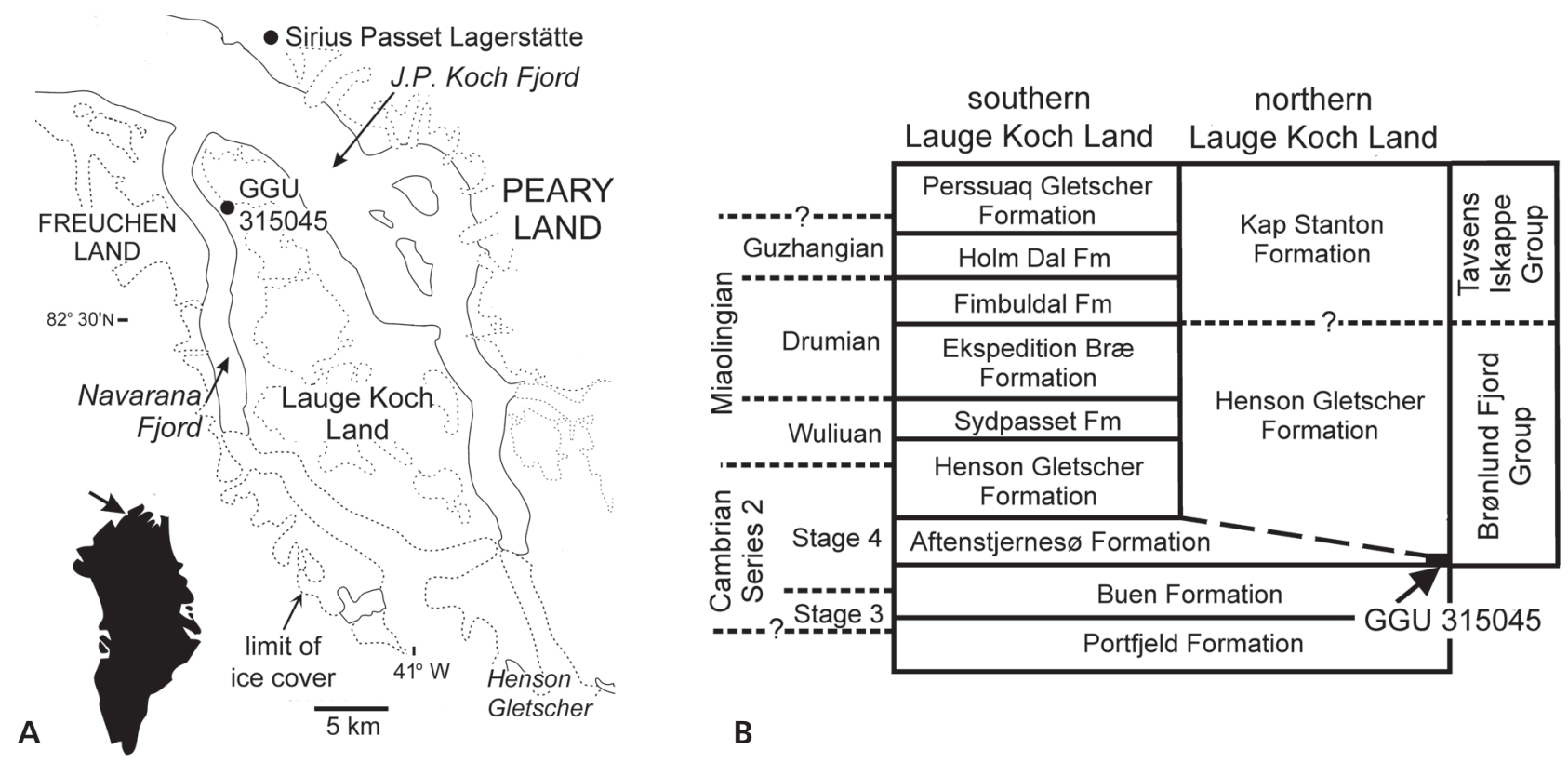

Figure 2. Collection locality (A) and Cambrian stratigraphy (B) in Lauge Koch Land, North Greenland for GGU sample 315045. Abbreviation: Fm - Formation.

the early-middle Cambrian gap in the record of potential aculiferan fossils noted by Vinther et al. (2017) is closed. The geological record of palaeoloricates is extended back by some 20 m.y., from the late Furongian to Cambrian Stage 4, potentially offering an earlier origin for crown group aculiferans than current models suppose (Vinther et al. 2017, Kocot et al. 2020).

The problematic fossil taxa discussed herein extend over $100 \mathrm{Ma}$ from the Cambrian (Terreneuvian) to the Silurian (Wenlock; Fig. 3). Crown group chitons (Order Chitonida) are known from the Carboniferous onwards, while multiplacophorans range from Silurian to Permian (Vinther et al. 2012b); extant aplacophorans have no fossil record.

\section{Geological background}

All described specimens are derived from the Aftenstjernesø Formation in Lauge Koch Land, North Greenland (Fig. 2). The Aftenstjernesø Formation is the lowest formation in the carbonate-dominated Brønlund Fjord and Tavsens Iskappe groups that prograded northwards into the deep water trough of the transarctic Franklinian Basin (Higgins et al. 1991, Ineson et al. 1994, Ineson \& Peel 1997). In southern Lauge Koch Land, the groups consist of an alternation of cliff-forming prograding coarse, crossbedded dolomitic grainstones with frequent debris flows, deposited during highstands of sea level, and recessive mudstone-limestone-dolomite units representing lowstand conditions (Higgins et al. 1991, Ineson \& Peel
1997; Fig. 2B). The alternation of highstand and lowstand deposition permits a lithostratigraphic subdivision that is not applied in northern Lauge Koch Land, where dark outer shelf mudstones and carbonates of the Henson Gletscher and Kap Stanton formations dominate the succession (Ineson et al. 1994) beyond the offshore limit of the prograding units (Fig. 2B).

The Aftenstjernesø Formation is mainly composed of dolostone grainstones, but a debris flow characteristically occurs at the top of the formation throughout the area. In southern Lauge Koch Land it attains a thickness of about $62 \mathrm{~m}$ (Ineson \& Peel 1997) but this is reduced to about $18 \mathrm{~m}$ at the collection locality in northern Lauge Koch Land (Fig. 2A). The formation represents the first establishment of carbonate deposition following sandstones and recessive mudstones of the Buen Formation. The latter formation crops out extensively across eastern areas of North Greenland and yields rich faunas indicative of Cambrian Stages 3 and 4 (Peel \& Willman 2018). The Sirius Passet Lagerstätte of northwestern Peary Land is located within basal strata of the Buen Formation transitional to a deep water trough siliciclastic succession to the north (Conway Morris et al. 1987; Ineson \& Peel 2011; Peel \& Ineson 2011a, b; Harper et al. 2019; Fig. 2). Fossils from the Aftenstjernesø Formation indicate Cambrian Stage 4 and are confined to the basal few metres of dolomitic grainstones that are rich in glauconite, phosphorite bioclasts, pyrite and phosphatised hardgrounds (Frykman 1980, Peel 2017). This distinctive horizon can be traced from southern to northern Lauge Koch Land and in outcrops across Peary Land to the east. 


\section{Material and methods}

Grønlands Geologiske Undersøgelse (GGU) sample 315045 was collected by J.S. Peel on $7^{\text {th }}$ of July 1984 from the basal beds of the Aftenstjernesø Formation in Lauge Koch Land, North Greenland (Fig. 2). The locality lies on the east side of Navarana Fjord, on the northern limb of a prominent east-west trending anticline, at an altitude of about $260 \mathrm{~m}$ a.s.1. $\left(82^{\circ} 36^{\prime} \mathrm{N}, 42^{\circ} 18^{\prime} \mathrm{W}\right)$. The sample was collected from about $60 \mathrm{~cm}$ above the base of Aftenstjernesø Formation, from within a blueblack weathering, bioclastic dolostone, $40 \mathrm{~cm}$ thick, with abundant pyrite and an irregular, phosphatized, upper surface.

The dolostone sample was dissolved in $10 \%$ acetic acid. Selected specimens were coated with gold prior to stereoscan microscopy, and images were assembled subsequently in Adobe Photoshop CS4.

Institutional abbreviations. - GGU - Grønlands Geologiske Undersøgelse, the Geological Survey of

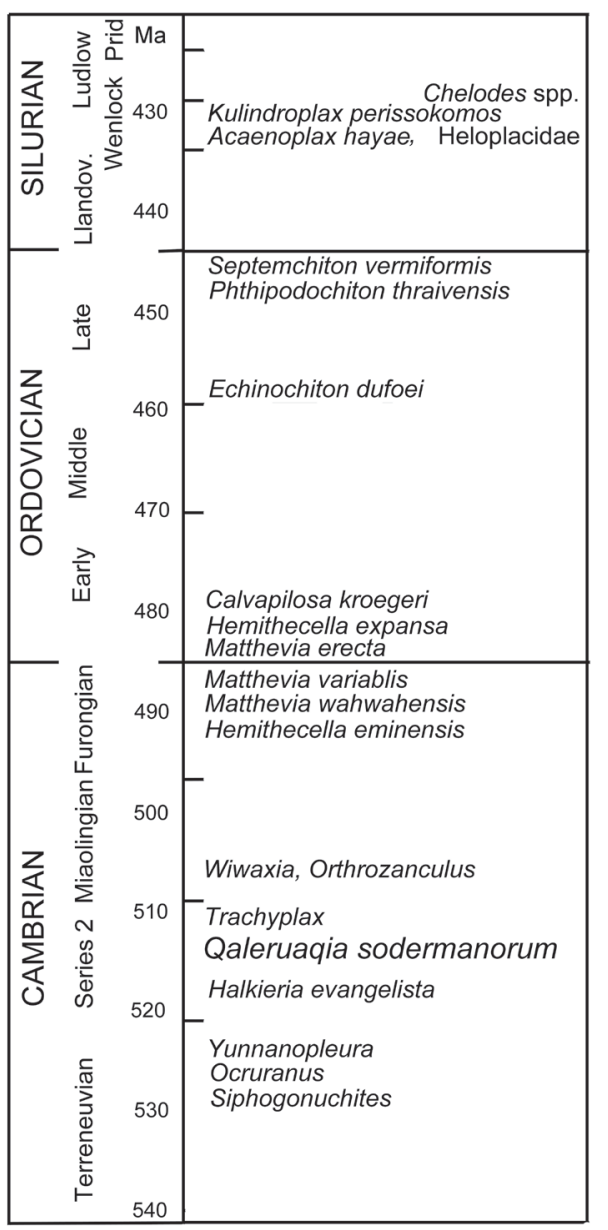

Figure 3. Geological record of aculiferan taxa mentioned in the text. Abbreviations: Llandov. - Llandovery; Prid. - Pridoli.
Greenland, now part of the Geological Survey of Denmark and Greenland (GEUS), Copenhagen, Denmark; MGUH Geological Museum, Copenhagen, now part of the Natural History Museum of Denmark; PMU - the paleontological type collection of the Museum of Evolution, Uppsala University, Sweden; SM - Sedgwick Museum, University of Cambridge, U.K.

\section{Systematic palaeontology}

This published work and the nomenclatural acts it contains have been registered in ZooBank database (International Commission on Zoological Nomenclature): http://zoobank.org/References/2C80D14F-6260-4A659E43-AE8460A129EC

Phylum Mollusca Linnaeus, 1758

Subphylum Aculifera Hatschek, 1891

Palaeoloricata Bergenhayn, 1955

Family Mattheviidae Walcott, 1886

Discussion. - Palaeoloricata was recognised as a subclass of Class Polyplacophora de Blainville, 1816 by Cherns (1998a, b) and Hoare \& Pojeta (2006) in their studies of Ordovician and Silurian polyplacophorans, although Runnegar et al. (1979), Vendrasco \& Runnegar (2004) and Pojeta et al. (2010) considered it to be an order. Palaeoloricates are a paraphyletic group including aplacophorans, chitons and stem group aculiferans (Sigwart \& Sutton 2007, Pojeta et al. 2010, Vinther 2015) and the name is used here informally. The original spelling Matthevidae of Walcott (1886, see also Yochelson 1966) was modified to Mattheviidae by Runnegar et al. (1979), Smith \& Hoare (1987) and later authors.

Pojeta et al. (2010) described three families in their revision of palaeoloricates from Furongian strata in Missouri, USA, giving a detailed review of earlier proposals. Mattheviids were characterised as having one or two deep lacunae and large apical areas on the intermediate valves. It is with members of this family that plates of Qaleruaqia gen. nov. are tentatively compared. Aulochitonids lack lacunae and have a small apical area, whereas dycheidiids, only questionably regarded as polyplacophorans by Pojeta et al. (2010), have shallow median lacunae, gaping intermediate plates but no apical area.

Questions of plate orientation and directional terminology in Matthevia and other palaeoloricates were discussed by Pojeta et al. (2010). As most material is disarticulated, the precise attitude of plates in life is unknown, particularly as regards the inclination of more elongate plates and the degree of overlap: various restorations have been presented (Vendrasco \& Runnegar 2004, Vinther 2014). Posterior and anterior in Qaleruaqia 
A

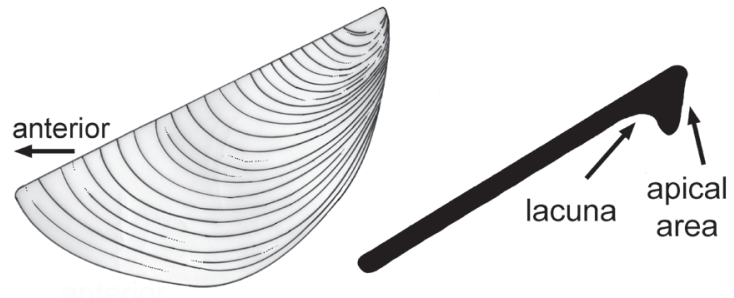

B

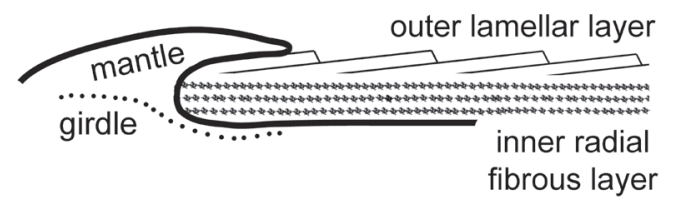

C

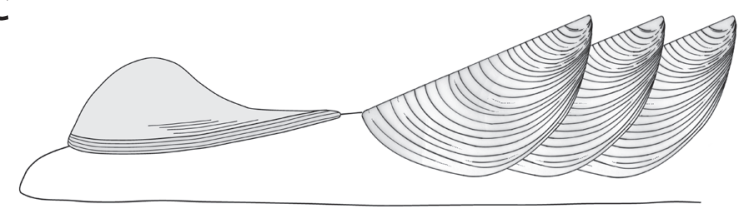

D

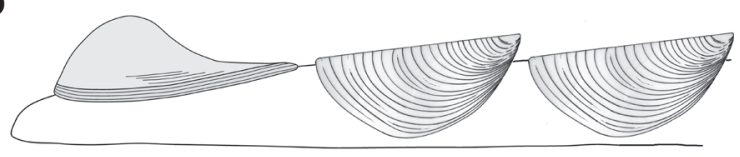

Figure 4. Interpretative sketches of Qaleruaqia sodermanorum gen. et sp. nov. $\cdot$ A - intermediate plate in lateral view and longitudinal section showing the disposition of the apical area and the shallow lacuna. • B - longitudinal section of shell near anterior margin of intermediate plate showing the overlapping comarginal lamellae in the outer layer downstepping towards the posterior and radial fibrous structure of the inner layer. $\bullet \mathrm{C}, \mathrm{D}$ - reconstructions of anterior end in lateral view (anterior to left), with overlapping (C) and sequential (D) intermediate plates.

are used here in accordance with the overall direction of growth in intermediate plates, but their degree of inclination is not known (Fig. 4A).

\section{Genus Qaleruaqia gen. nov.}

LSID. - 1sid:zoobank.org:act:44F403B6-EAF3-42769463-2A5FD410115A

Type species. - Qaleruaqia sodermanorum gen. et sp. nov., from the lower Aftenstjernesø Formation, Navarana Fjord, Lauge Koch Land, North Greenland, Cambrian Series 2 , Stage 4 , by monotypy.

Etymology. - From 'Qaleruaq', Greenlandic, meaning shell; feminine.

Diagnosis - Intermediate plate oval, with sub-parallel sides in dorsal perspective (Fig. 5B), saddle-shaped in lateral view with convex antero-lateral margins (Fig. 5C). Postero-lateral marginal areas shallowly concave in dorsal view, forming wing-like structures adjacent to the convex middorsal area. Apical area about as long as broad, with broad transverse ribs fading laterally; lacuna very shallow. Shell growth mixoperipheral with dorsal ornamentation of comarginal ridges. Outer shell layer formed by imbricating lamellae which slope towards the antero-lateral margins, with each lamella overlying the previous lamella. Inner shell layer with radial fibrous structure.

Head plate oval, width about two thirds of length, with a short, convex supra-apical surface and a long, concave sub-apical surface. Early growth stage bulbous, located nearer to the slightly pointed, supra-apical margin. Concave sub-apical train with sub-quadrangular and slightly arched margin. Holoperipheral growth, with ornamentation of comarginal cords that is traversed by broad radial folds on the sub-apical surface near the margin.

Discussion - Qaleruaqia is known from isolated sclerites of the type species Qaleruaqia sodermanorum gen. et sp. nov. that are considered to represent head and intermediate plates (Figs 4-6). The presence on the ventral surface of the apical area and shallow lacuna supports interpretation of the intermediate plates of Qaleruaqia gen. nov. as the intermediate plates of a mattheviid palaeoloricate similar to Chelodes Davidson \& King, 1874 (Cherns 1998a, b). The sclerite interpreted as the head plate resembles the head plate of Matthevia variablis Walcott, 1885 (Runnegar et al. 1979) and Matthevia wahwahensis Vendrasco \& Runnegar, 2004 from the Furongian of USA. However, the intermediate plates of Matthevia are heavily calcified with one or more deep lacunae.

Both plate morphotypes of Qaleruaqia occur together in GGU sample 315045 from the basal Aftenstjernes $\varnothing$ Formation of Navarana Fjord, Lauge Koch Land (Fig. 2). It is not known how many intermediate plates, and possibly a discrete tail plate, are present within the scleritome. The available sample, however, is very small, with only three known specimens of the intermediate plate of Qaleruaqia sodermanorum and two head plates.

Other species. - Known only from the type species at the type locality.

\section{Qaleruaqia sodermanorum sp. nov.}

Figures 4-6

LSID. - 1sid:zoobank.org:act:6CEE7CDE-4C86-412DB5C7-AEA12E103150

Types. - Holotype: PMU 36057 from GGU sample 315045, Aftenstjernesø Formation, Navarana Fjord, Cambrian Series 2, Stage 4. 
Paratypes: Intermediate plates PMU 36058 and PMU 36059, and head plate PMU 36060, from the same sample and locality as the holotype.

Type horizon and locality. - Lower Aftenstjernesø Formation (Brønlund Fjord Group; Fig, 2B), eastern side of Navarana Fjord, Lauge Koch Land, North Greenland; Cambrian Series 2, Stage 4.

Material. - Known only from the four illustrated specimens (Figs 5,6) and one additional head plate, all from GGU sample 315045. All specimens are secondarily phosphatised, originally calcareous.

Etymology. - For Gudrun and Einar Söderman (Uppsala).

Diagnosis. - As for genus.

Description. - In dorsal external view, the bilaterally symmetrical intermediate plate appears to be oval in shape, with parallel or sub-parallel sides and uniformly rounded terminations (Fig. 5B). In lateral view, however, its form is seen to be saddle-shaped, with the lateral areas forming convex shields which meet their maximum height of half the length at about two thirds of the distance from the presumed posterior margin (uppermost in Fig. 5B) to the anterior margin (Fig. 5C). The plate is flat along the median plane from posterior to anterior. At the posterior, the median dorsal area is initially convex, but becomes concave laterally (Fig. 5B). These concave areas narrow anteriorly as the initial medially convex area expands to encompass the entire surface.

Ventrally, the apical area of the plate is developed as a prominent shelf extending anteriorly into the interior from the posterior, and with a slight overhang at its anterior margin delimiting a shallow lacuna (Fig. 5L). The anterior margin of the apical area is excavated medially and its surface is marked by a series of W-shaped low, rounded, transverse ridges and intervening channels which increase in amplitude from posterior to anterior (Fig. 5E, L). About seven ridges are present, fading away laterally. The surface is generally smooth, but a patch of cellular structure, with a network of depressed ridges around raised centres, is preserved just antero-lateral of the ridges (Fig. 5K, arrows). Details of the internal surface at the anterior of the plate are not known.

Plate growth is mixoperipheral. The dorsal surface of the intermediate plate is marked by a uniform series of comarginal ridges spaced at about 5 or 6 per $100 \mu \mathrm{m}$ near the anterior margin (Fig. 5G). The ridges are asymmetric in cross-section, steepened on the side facing the posterior (Fig. 5A, arrow $\mathrm{cml}$ ), forming an imbricate stack of comarginal laminae in which the latest deposited lamella lies uppermost and slopes towards the antero-lateral margins (Fig. 6B-D). The lamellae are thus down-stepping towards the posterior (Figs 5A, 6C). The comarginal ridges fade at the transition to the postero-lateral wing-like areas (Fig. 5B). In the holotype, this distal termination of the ridges is related to the loss of the thin outer shell layer which carries the ridges. A broken margin (arrows in Fig. 5A; Fig. 6B) separates this ridge-bearing outer layer from an underlying layer characterised by a faint radial fibrous structure. The same fibrous layer is evident at the broken anterior margin of the sclerite (Fig. 5D; Fig. 6A, arrows).

The bilaterally symmetrical head plate is oval with width about two thirds of length (Fig. 6E). A bulbous initial growth stage lies nearer to the slightly pointed supra-apical margin, interpreted as anterior (Fig. 6C, D). The supra-apical surface is convex whereas the longer subapical surface is concave (Fig. 6G), with a sub-rectangular margin, in dorsal view. Growth is holoperipheral, with comarginal cords and interspersed fine growth lines; down-stepping of growth lamellae is towards the plate margin. Three or four weakly defined, broad radial folds traverse the sub-apical surface near the margin (Fig. 6F).

Discussion. - The outer surface of the holotype of Qaleruaqia sodermanorum is pierced by numerous small holes, the irregular form, size and distribution of which usually reflect imperfect phosphatisation (Figs 5F, 6A). However, many holes with a more regular circular cross-section and diameter of 20-30 $\mu \mathrm{m}$ (Fig. 6I) appear to have a biogenic origin. Their scattered nature may suggest microborings (Stockfors \& Peel 2005a, b) but sensory pores (aesthetes) are a character of the outer shell layer of polyplacophorans (Schwabe 2010) and can be highly variable in form (Vendrasco et al. 2009); they are reported also from Palaeozoic material (Hoare 2000, 2009; Vendrasco \& Runnegar 2004). Pojeta et al. (2010) reported a series of horizontal canals interpreted as aesthetes within the dorsal area of intermediate plates of Hemithecella eminensis Stinchcomb \& Darrough, 1995 with diameters ranging from 110-280 $\mu \mathrm{m}$, significantly larger than the vertical holes observed here in Qaleruaqia sodermanorum that are of similar size to the aesthetes of most modern chitons (Vendrasco et al. 2009). No vertical canals were observed in Hemithecella eminensis by Pojeta et al. (2010).

Intermediate plates of most described mattheviid taxa differ from Qaleruaqia sodermanorum in being posteriorly acuminate, with a long, narrow apical area (Cherns 1998a, b; Vendrasco \& Runnegar 2004; Hoare \& Pojeta 2006; Pojeta et al. 2010). The posterior is more bluntly rounded in Qaleruaqia sodermanorum. Growth lines at the broken posterior termination are divergent rather than convergent on an apex (Fig. 5G, J), suggesting that the transition from the dorsal surface to the apical area probably was a short transverse fold. The apical area is short, almost an equiangular triangle in preserved 


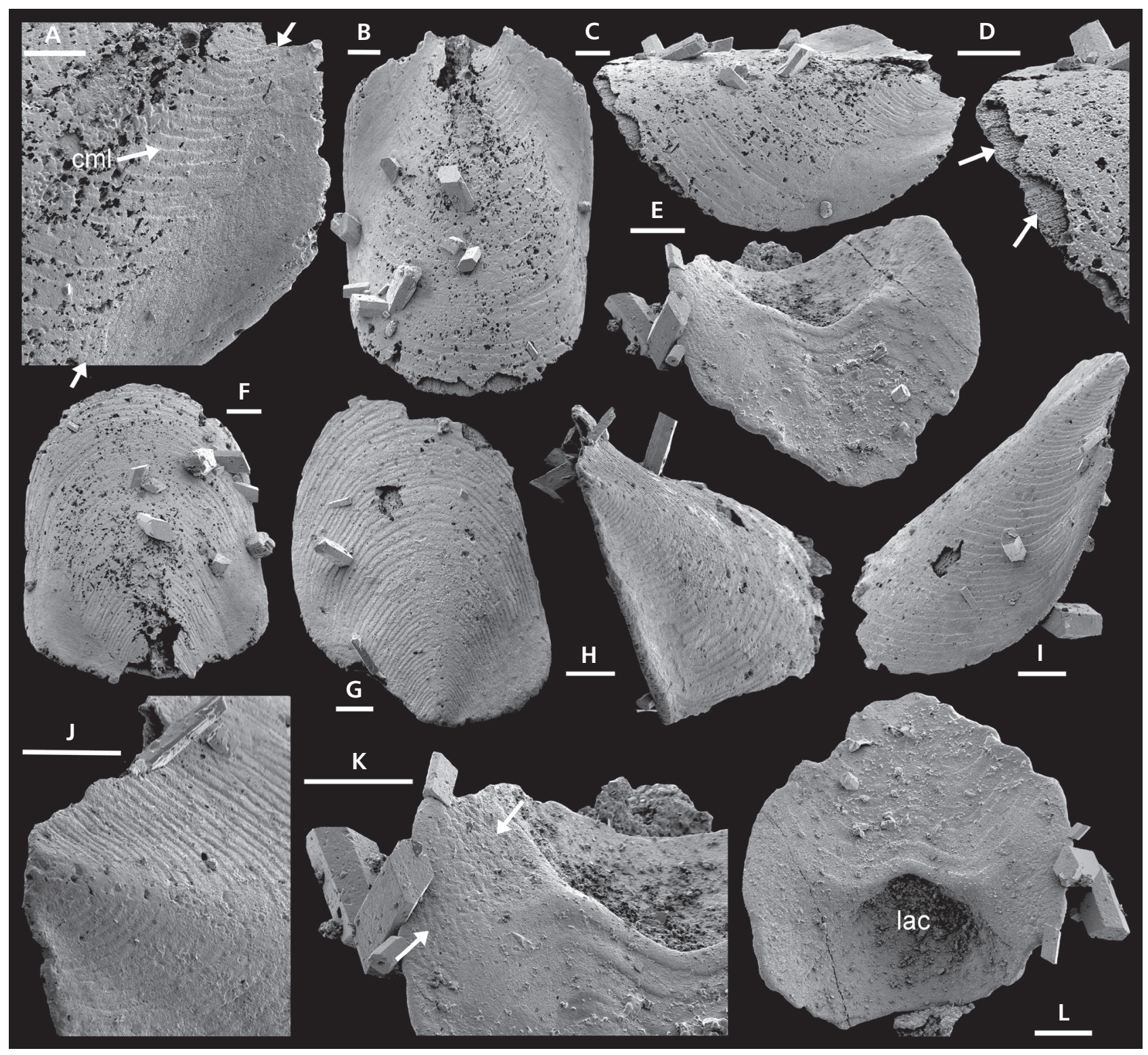

Figure 5. Qaleruaqia sodermanorum gen. et sp. nov., intermediate plates, Aftenstjernesø Formation, Navarana Fjord, Cambrian Series 2, Stage 4. All specimens from GGU sample 315045. A-D, F - PMU 36057, holotype, A - detail of postero-lateral margin showing comarginal lamellae (cml), with arrows indicating boundary between outer lamellar shell layer and inner radial fibrous layer, B - dorsal view with posterior at top, C - oblique lateral view, D - detail of anterior margin showing radial fibrous layer (arrows), F - postero-dorsal view with anterior at top; E, K, L - PMU 36058, apical area with growth lamellae, E - oblique posterior view, $\mathrm{K}$ - detail of wrinkled structure (arrows), L - plan view of apical area and shallow lacuna (lac); G-J - PMU 36059, dorsal surface with comarginal lamellar ornamentation, G - dorsal view, H - oblique postero-lateral view, I - oblique lateral view, $\mathrm{J}$ - detail of posterior (damaged) showing divergent comarginal ornamentation. Scale bars: $100 \mu \mathrm{m}$.

specimens (Fig. 5L). The anterior margin is uniformly convex in dorsal view, lacking the median sinus seen in the intermediate plates of most other genera (Cherns 1998a, b; Hoare \& Pojeta 2006; Pojeta et al. 2010). Intermediate plates of the Furongian-Early Ordovician Matthevia Walcott, 1885 are narrow and strongly tapering towards the posterior, with a deep median dorsal sinus and an apical area that is often more than half of the total length (Yochelson 1966, Vendrasco \& Runnegar 2004,
Pojeta et al. 2005). Plates of Matthevia are massively thickened with one or two deep lacunae, in contrast to the relatively thin-shelled Qaleruaqia sodermanorum, which has only a single shallow lacuna (Fig. 4A; Fig. 5L, lac).

Hemithecella Ulrich \& Bridge, 1941 (FurongianEarly Ordovician) has triangular intermediate plates that are often extremely long and narrow in contrast to the oval form of Qaleruaqia sodermanorum. The apical area extends to more than half the plate length above an almost 
cylindrical lacuna (Stinchcomb \& Darrough 1995, Pojeta et al.2010) that is much longer than the shallow lacuna of Qaleruaqia sodermanorum (Figs 4A, 5L).

Chelodes Davidson \& King, 1874 is best known through the detailed monograph of Silurian type material from Gotland, Sweden, by Cherns (1998a), although Runnegar et al. (1979) and Pojeta et al. (2010) assigned Furongian and Early Ordovician material to the genus. Intermediate plates are sub-triangular, almost as wide as long in the Gotland material, but Ordovician material assigned to the genus by Runnegar et al. (1979) and Pojeta et al. (2010) has elongate triangular plates. A shallow median dorsal sinus is usually present in the anterior margin of intermediate plates. However, the head plate of Chelodes actinis Cherns, 1998a from Gotland has an elongate shape in dorsal perspective similar to that of the intermediate plates of Qaleruaqia. The Greenland species differs from Chelodes actinis in its greater height in lateral perspective (Fig. 4C) and in having a more prominent apical area.

Many Cambrian and Ordovician specimens figured by Hoare \& Pojeta (2006) and Pojeta et al. (2010) are relatively poorly preserved and details of ornamentation are obscure. Hemithecella eminensis Stinchcomb \& Darrough, 1995 and Hemithecella expansa Ulrich \& Bridge, 1941, illustrated by Pojeta et al. (2010) from the Furongian of Missouri, display comarginal growth lines which display periodic rugae in the anterior part of the plate. A median dorsal sinus is present, in contrast to the uniformly convex anterior margin of Qaleruaqia sodermanorum, the latter also differing in the slope of growth lamellae towards the anterior, with the lamellar stack down-stepping to the posterior (Figs 5A, 6B).

The head plate of Qaleruaqia sodermanorum closely resembles the head shield of Matthevia in its low form, oval shape and inflated early growth stage (Fig. 6E-H). The head plate of Matthevia variablis was illustrated by Walcott (1885, fig. 3; 1886, pl. 32, fig. 4) and the illustration was reproduced by Yochelson (1966, pl. 1, fig. 18) who commented that the specimen was missing. Runnegar et al. (1979, pl. 1, fig. 23) illustrated a specimen from the Furongian Hoyt Limestone of New York, which appears to be the original figured specimen of Walcott $(1885,1886)$. Walcott $(1885,1886)$ considered the plate to be an operculum, but Yochelson (1966) doubted this interpretation, but he did not include it in his reconstruction of Matthevia. English (2002) described collections from the type locality of Matthevia variabilis at Skidmore Quarry, near Saratoga Springs, New York, but did not locate the head shield in his studied material. He restored Matthevia with a conical head plate but noted that the flat plate occurred in samples from a separate horizon. The head plate of Qaleruaqia sodermanorum differs from that of Matthevia variablis and Matthevia wahwahensis Vendrasco \& Runnegar, 2004 in having a more swollen apex and being slightly pointed at the supra-apical margin, whereas in Matthevia variablis it is equally rounded at both extremities.

Runnegar et al. (1979) considered that the swollen apex of Matthevia lay closer to the posterior margin but a reconstruction of Matthevia wahwahensis by Vendrasco \& Runnegar (2004, fig. 4.3) placed it closer to the anterior margin, see also Vinther et al. (2012a, fig. 4c). This interpretation, with the convex supra-apical surface located anteriorly, is favoured here in Qaleruaqia sodermanorum on account of the shallow arching of the subapical margin and the slightly pointed supra-apical margin (Figs 4C, D; 6E-H).

\section{Shell formation in Qaleruaqia}

The imbrication of comarginal growth lamellae of intermediate plates shows down-stepping of individual lamellae towards the posterior (Figs 4B, 5A, 6C), indicating that shell growth in the mixoperipheral intermediate plates of Qaleruaqia sodermanorum was accomplished in similar fashion to that described in present day chitons by Beedham \& Trueman (1967) and Checa et al. (2017). In extant chitons, and also in Qaleruaqia, calcareous skeletal elements are anchored firmly in the mantle tissues and the secreting edge embraces the outer margin. In contrast, the body in conchiferan molluscs moves separately from the periostracum and shell, a development that enables the animal to withdraw or extend its soft parts, and shell growth takes places on the inner surface beneath previous layers. Withdrawing into its shell provides enhanced safety while the chiton's defensive solution is to armour its exposed girdle with a myriad of small calcareous spicules in the tissues surrounding the shells and to clamp or enrol (Todt et al. 2008, Schwabe 2010, Sigwart et al. 2019).

Comarginal holoperipheral growth ornamentation on the head plate of Qaleruaqia does not show comparable down-stepping to that seen in the intermediate plates, but rather a down-stepping pattern towards the margin similar to that seen in Halkieria and other molluscs.

Surprisingly, the distinctive imbricate style of shell growth seen in the intermediate plates of Qaleruaqia has not been reported in other palaeoloricates, although most of the material from Laurentia described by Hoare \& Pojeta (2006) and Pojeta et al. (2010) is internal moulds lacking details of ornamentation. Excellently preserved Silurian specimens of Chelodes clearly show downstepping of growth lamellae on the intermediate plates towards the anterior margin (Cherns 1998a, pl. 3) whereas down-stepping in Qaleruaqia is towards the posterior (Figs 5A, 6C). It is likely that the posterior down-stepping in intermediate plates of Qaleruaqia represents an unusually high degree of marginal overlap 


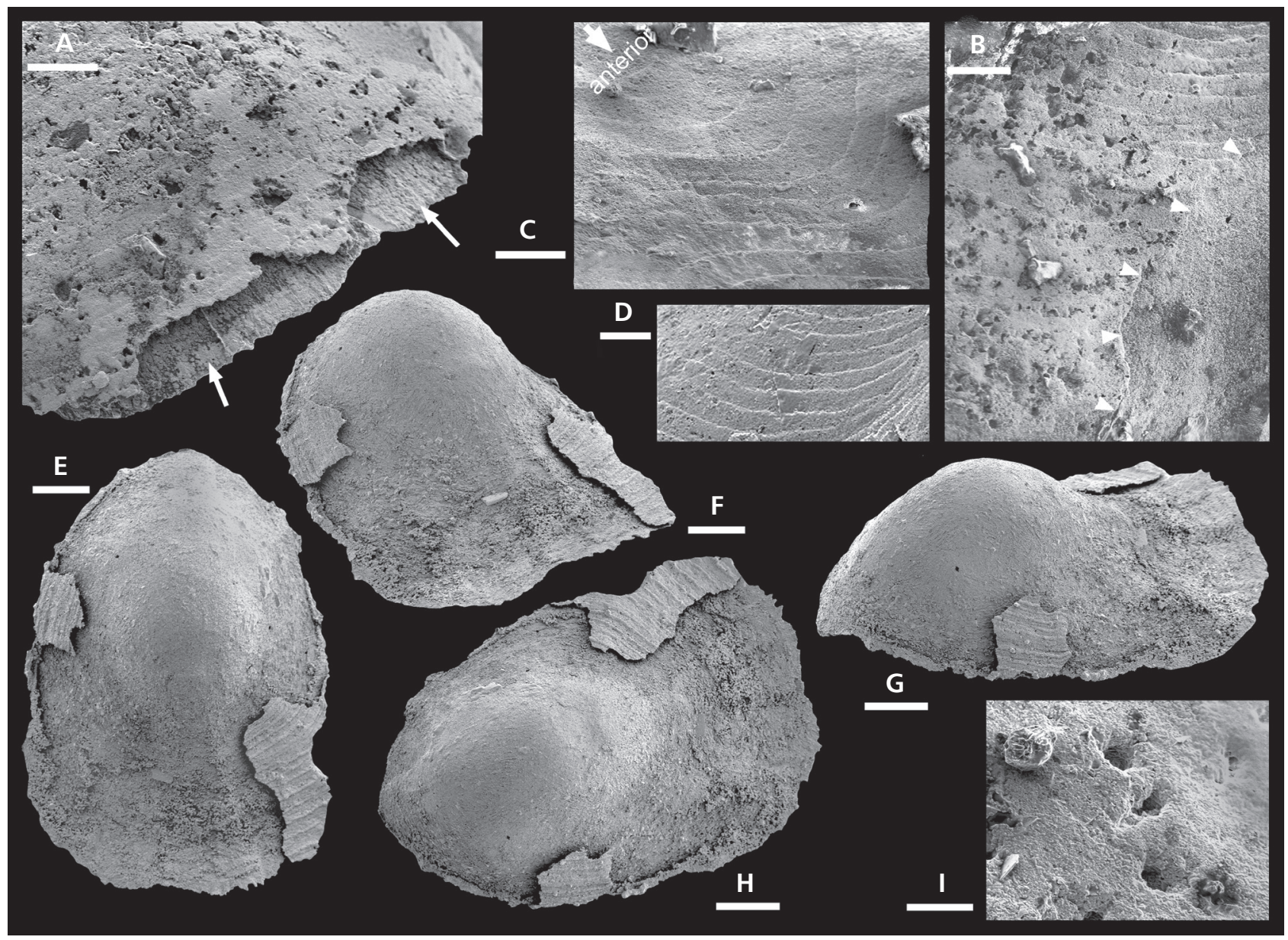

Figure 6. Qaleruaqia sodermanorum gen. et sp. nov., Aftenstjernesø Formation, Navarana Fjord, Cambrian Series 2, Stage 4. All specimens from GGU sample 315045. A, B, I - PMU 36057, holotype, intermediate plate, A - detail of anterior margin showing outer shell layer with comarginal lamellar growth ornamentation overlying inner shell layer with radial fibrous structure, B - detail of postero-lateral area (Fig. 5A) showing boundary (arrows) between outer shell layer with comarginal lamellar growth ornamentation overlying inner layer with radial fibrous structure, I - perforations in dorsal surface; C, D - PMU 36059, intermediate plate showing details of lateral area (D) and of apical area (C) of specimen illustrated in dorsal view in Fig. 5G-J, showing imbricated growth lamellae; E-H - PMU 36060, head plate in dorsal (E) and oblique dorso-lateral (F-H) views, with outer shell layer largely exfoliated. Scale bars: $10 \mu \mathrm{m}$ (I), $30 \mu \mathrm{m}$ (C), $50 \mu \mathrm{m}$ (A, B, D), $100 \mu \mathrm{m}(\mathrm{E}-\mathrm{H})$.

of the dorsal surface by the mantle. Anterior downstepping in the head plate and in plates of other palaeoloricates may have resulted from the mantle embracing the inner shell layer (fibrous in Qaleruaqia, Fig. 6A) but having edge-to-edge contact with just the outer edge of the overlying outer lamellar layer (Beedham \& Trueman 1967, fig. 4a; Checa et al. 2017, fig. 8a).

Down-stepping of growth lamellae towards earlier growth stages is seen in several Cambrian mollusclike taxa where the outer shell layer is scaly, including Yunnanopleura Yu, 1987, discussed below (Qian \& Bengtson 1989, Kouchinsky et al. 2015). A similar imbrication of growth lamellae resulting from accretion on the outer surface of a sclerite embedded in tissue was described by Peel (2019) in the paraconodont Tarimspira artemi Peel, 2019 from the lower Cambrian (Cambrian Series 2, Stage 4) of North Greenland.

\section{Qaleruaqia and micropolyplacophorans}

Vendrasco et al. (2009) revived interpretation of the Ocruranus-Eohalobia group as possible stem group chitons in accordance with the micropolyplacophoran hypothesis of $\mathrm{Yu}(1987,2001,2014)$ concerning mainly Chinese material from Cambrian Series 1. Thus, Eohalobia Jiang, 1980, interpreted as the head plate, was placed in synonymy with Ocruranus Liu, 1979 interpreted as the tail plate with the scleritome completed by an intermediate valve assigned to ?Gotlandochiton. Vendrasco et al. (2009) acknowledged that the first undisputed chitons (i.e. at that time the palaeoloricate Matthevia) occurred in the Furongian (Runnegar et al. 1979, Pojeta et al. 2010; Fig. 3), although Matthevia was placed within the aplacophoran line by Sutton et al. (2012) and Vinther et al. (2017). This first appearance of a palaeoloricate is revised 
herein to Cambrian Series 2, Stage 4 with the description of Qaleruaqia sodermanorum (Fig. 3).

Vinther (2015) seems to have regarded these problematic Chinese fossils as probable stem group sachitids filling the gap between the earliest conchiferans and the appearance of the aculiferans. While the Ocruranus scleritome was interpreted as including head, intermediate and tail plates (Vendrasco et al. 2009), the contemporary association of disarticulated scaly caps such as Maikhanella Zhegallo in Voronin et al., 1982 and spinose sclerites of Siphogonuchites Qian, 1977 was regarded as representing a single plated form like Calvapilosa by Vinther et al. (2017). Kouchinsky et al. (2017) discussed the association of Purella Missarzhevsky, 1974 and Yunnanopleura Yu, 1987 from Cambrian Series 1 (Terreneuvian) in Siberia (Fig. 3) as opposing anterior and posterior plates in the same scleritome, probably in association with siphogonuchitid-type sclerites, an arrangement comparable to Halkieria. Thus, at least three different plate arrangements have been suggested in these early Cambrian forms, but articulated specimens are not known.

Only Yunnanopleura of the numerous shells described by Yu (1987), Qian \& Bengtson (1989) and Parkhaev \& Demidenko (2010) develops a prominent apical area. On this basis it was interpreted by $\mathrm{Yu}(1987,2014)$ as an intermediate plate comparable to Chelodes. The elongate shell is about twice as long as wide and has a pointed apex (?posterior) that overhangs the sub-apical margin. The apical area is about one fifth of the total length of about $2 \mathrm{~mm}$ and may show conspicuous lamellae that down-step towards the supra-apical margin as in Qaleruaqia (Qian \& Bengtson 1989, fig. 62). The interpretation of these prominent growth lamellae on the apical area as dentition by Parkhaev \& Demidenko (2010) is rejected. Thus, growth is mixoperipheral in the Chinese material, as in Qaleruaqia. Down-stepping of growth lamellae towards the mid-dorsum is seen on the apico-lateral margins in specimens assigned to Yuannopleura (Kouchinsky et al. 2017, fig. $36 b_{2}$ ) and possibly Yu (2014, fig. 1.3), but most of the dorsal ornamentation of comarginal growth lines in the material from the Anabar Uplift of Siberia, and in specimens illustrated by $\mathrm{Yu}(1987,2014)$ from Meisuchun, shows down-stepping of lamellae towards the margin.

The restoration proposed by Kouchinsky et al. (2017) regarded Yunnanopleura as the tail plate, Purella as the head plate and (presumably) a thorax covered with pointed siphogonuchitid sclerites, in similar fashion to Halkieria (Fig. 7E). Their comparison to the posterior plate of Halkieria implies that the apex of Yunnanopleura was located anteriorly and not posteriorly as suggested by $\mathrm{Yu}$ (1987), which is inconsistent with the presence of an apical area in the Chinese material (Yu 1987). An apical area is lacking in plates of Halkieria and not visible in illustrations of the Siberian material attributed to Yunnanopleura by Kouchinsky et al. (2017).

Yunnanopleura differs from intermediate plates of Qaleruaqia in its pointed posterior and its coplanar margin. In Qaleruaqia the intermediate plate is saddleshaped in lateral perspective (Fig. 5B). However, similarity in the development of an apical area and corresponding mixoperipheral growth in Yunnanopleura from the Terreneuvian (Meisuchunian) of China suggests a possible link to younger palaeoloricates such as Qaleruaqia, Matthevia and Chelodes.

\section{Restoring Qaleruaqia as a palaeoloricate}

Complete specimens of multisclerite molluscs are rare in the Palaeozoic and restorations based on isolated sclerites are usually rooted in their predetermined taxonomic position. Pojeta et al. (2010) noted that no articulated chiton scleritomes were known from the Cambrian. Matthevia (Furongian-Early Ordovician) has been considered to be the oldest palaeoloricate chiton, with the status of the micropolyplacophorans of Yu (1987) being equivocal (Qian \& Bengtson 1989, Vendrasco et al. 2009, Pojeta et al. 2010, Vinther 2015).

Walcott $(1885,1886)$ considered Matthevia to be a pteropod with two skeletal elements, subsequently interpreted as the head plate (interpreted as an operculum by Walcott 1885, 1886) and intermediate plates (Runnegar et al. 1979, Vendrasco \& Runnegar 2004). Yochelson (1966) restored Matthevia with two plates, excluding the head plate, in his novel reconstruction that formed the basis for Class Mattheva Yochelson. 1966. Runnegar \& Pojeta (1974, fig. 5) considered the scleritome of Matthevia to include seven or eight plates, with their reconstruction showing seven, and this figure was cited also by Runnegar et al. (1979). English (2002, fig. 4) proposed eight plates (but excluding a flat head plate). Eight plates including the flat head plate were retained in reconstructions made by Vendrasco \& Runnegar (2004, fig. 4), Vinther (2014, fig. 2) and Vinther et al. (2012a, fig. 4c). However, the actual number of plates in the scleritome of Matthevia is not known. There are eight plates in the unusual chiton Echinochiton Pojeta, Eernisse, Hoare \& Henderson, 2003 from the Middle Ordovician of Wisconsin (Pojeta et al. 2003, Pojeta \& DuFoe 2008; Fig. 3) and in the Late Ordovician Septemchiton Bergenhayn, 1955 (Rolfe 1981; Fig. 3). However, Sutton et al. (2012) considered Septemchiton to be a crown group aplacophoran, placing the genus together with the 7-plated Acaenoplax Sutton, Briggs, Siveter \& Siveter, 2004 and Kulindroplax from the Silurian (Sutton et al. 2004, 2012). Cherns (2004) proposed a Family Heloplacidae for several forms from the Silurian of Gotland, Sweden, related to Acaenoplax (Fig. 3). 


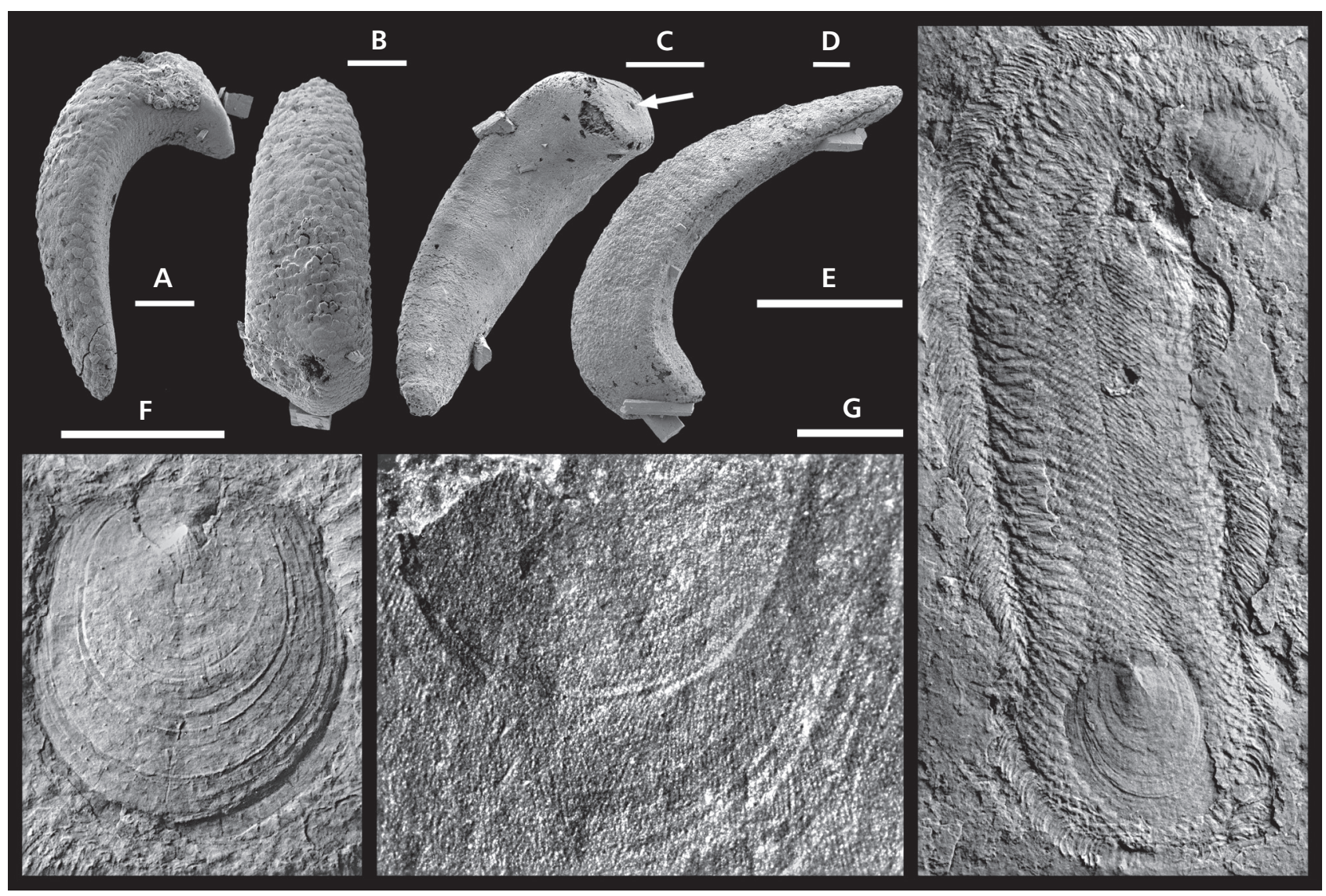

Figure 7. Halkieria and Hippopharangites from North Greenland (Cambrian Series 2). A-D - Hippopharangites sp., Aftenstjernesø Formation, Navarana Fjord, Cambrian Series 2, Stage 4. All specimens from GGU sample 315045; A, B - PMU 36061, lateral view (A) and convex surface (B) showing scales; C - PMU 36062, oblique view of concave surface with transverse ridges and basal facet with central foramen (arrow); D - PMU 36063, lateral view. • E-G - Halkieria evangelista Conway Morris \& Peel, 1995, Transitional Buen Formation, Sirius Passet Lagerstätte, Cambrian Series 2, Stage 3; E - MGUH 19728, holotype, with anterior turned to right; F - SM X24926, posterior shell; G - MGUH 19730, detail of posterior shell showing fans of sub-radial lines crossing comarginal growth lines (photo: Simon Conway Morris). Scale bars: $100 \mu \mathrm{m}(\mathrm{A}-\mathrm{D}), 1 \mathrm{~mm}(\mathrm{G})$, $10 \mathrm{~mm}(\mathrm{~F}, \mathrm{G})$.

Conventional restoration of Qaleruaqia as a palaeoloricate chiton suggests a head plate followed by six intermediate plates and a tail plate, which may be closely similar morphologically to the intermediate plates, as has been proposed in Matthevia. This is more plates than available specimens in the current small sample of Qaleruaqia sodermanorum, where a posterior plate is not known. The partial restorations (Fig. 4C, D) portray just the anterior part of the animal and the inclination and degree of overlap of the intermediate plates is arbitrary. The uniformly convex anterior margin of the intermediate plates may suggest no overlap of plates (Fig. 4D) as an anterior sinus is usually present in overlapping plates (Cherns 1998a, b; Hoare \& Pojeta 2006). Alternatively, the height and convex form of the plate in lateral view (Fig. 5C) and the development of an apical area may be an indication of overlap (Fig. 4C), although the relative shortness (posterioranterior) of the apical area suggests that the plates were not so steeply inclined as in Matthevia or Hemithecella.

\section{Qaleruaqia and halkieriids}

Halkieria evangelista Conway Morris \& Peel, 1995 is undoubtedly the most cited Cambrian fossil yet described from North Greenland and continues to form a central element in discussions of lophotrochozoan evolution (Conway Morris \& Peel 1995, Vinther \& Nielsen 2005, Conway Morris \& Caron 2007, Vinther et al. 2017, Zhao et al. 2017, Han et al. 2019) The up to $8 \mathrm{~cm}$ long fossil was a slug-like animal in which the dorsal surface is covered by a chain mail of many hundred small pointed sclerites, with prominent plates at the anterior and posterior (Fig. 7E, F). Comparison of the plates of Qaleruaqia sodermanorum with these anterior and posterior plates is apposite, not only on account of morphological similarity, but also due to the occurrence together with Qaleruaqia sodermanorum in GGU sample 315045 of disarticulated halkieriid sclerites assigned to Hippopharangites Bengtson in Bengtson et al., 1990 (Fig. 7A-D). 
Fully articulated specimens of Halkieria evangelista are a key element in the diverse fauna of the Sirius Passet Lagerstätte (Conway Morris et al. 1987; Conway Morris \& Peel 1995; Ineson \& Peel 2011; Peel \& Ineson 2011a, b; Harper et al. 2019). The single locality with exceptionally preserved fossils (Fig. 2A) lies in strata assigned to Cambrian Stage 3 (Montezuman Stage of Laurentian usage) in the lower part of the Buen Formation (Babcock \& Peel 2007, Hollingsworth 2011).

Intermediate plates of Qaleruaqia sodermanorum viewed in dorsal perspective display a superficial resemblance to the posterior plate of Halkieria evangelista (Fig. $7 \mathrm{E}, \mathrm{F})$ but are considered to be oriented differently. Thus, the narrower end of the intermediate plate in Qaleruaqia (uppermost in Fig. 5B) is interpreted as posterior, whereas the apex of the posterior plate in Halkieria is anterior (Fig. 7E, F). The posterior plate in Halkieria has holoperipheral growth, whereas growth in intermediate plates of Qaleruaqia is mixoperipheral. In contrast to Qaleruaqia, there is no indication of an apical area in Halkieria. The well developed, sub-marginal, anterior apex of Halkieria is not seen in Qaleruaqia where growth lamellae diverge slightly at the margin, suggesting a transverse fold, rather than converge on a single point (Fig. 5J). The shell margins are coplanar in Halkieria whereas Qaleruaqia is strongly saddle-shaped in lateral view (Fig. 5C, I).

The anterior plate in Halkieria is oriented with its apex overhanging the posterior margin, as is the case also with the earliest growth area in Qaleruaqia, but Halkieria is wider than long, and convex along the median dorsal plane (Conway Morris \& Peel 1995). The head plate of Qaleruaqia has similar curvature to the anterior plate of Halkieria, with the convex supra-apical surface interpreted as anterior. In the latter, however, the apex lies at the posterior margin whereas initial growth in the head plate of Qaleruaqia was near to the anterior.

Comarginal ornamentation in intermediate valves of Qaleruaqia differs profoundly from the anterior and posterior plates of Halkeria in that shell lamellae in Qaleruaqia are deposited externally on top of preceding shell layers at the growing edge, down-stepping towards the posterior (Figs 5B, C, E; 6C, D). Successive shell layers appear to have been added internally, underneath earlier growth lamellae in Halkeria (Fig. 7F). However, this latter form of accretional growth is seen in the head plate of Qaleruaqia, intermediate valves of palaeoloricates, and most other molluscs. Halkeria plates may show a sub-radial ornamentation consisting of fans of fine lines which do not originate at the apex (Fig. 7G). They may be a reflection of shell structure and, as such, can be compared to the radially fibrous inner shell layer of Qaleruaqia (Figs 5C, D; 6A). Similar fibrous structure is known from other Cambrian molluscs, including Ocruranus and pelagiellids (Vendrasco et al. 2009).
Conway Morris \& Peel (1995) described three types of small sclerites occurring in articulated specimens of Halkieria evangelista (Fig. 7E) of which the cultrate sclerites most closely resemble the sclerites of Hippopharangites that occur together with Qaleruaqia in GGU sample 310345 (Fig. 7A-D). These Hippopharangites sclerites display the characteristic scale-like tubercles on their convex surface described by Bengtson et al. (1990), whereas the cultrates of Halkeria evangelista are longitudinally ribbed.

\section{Qaleruaqia and Calvapilosa}

Calvapilosa kroegeri Vinther, Parry, Briggs \& Van Roy, 2017 from the Fezouata Formation Lagerstätte (Ordovician, Tremadocian) of Morocco is characterised by an elongate mantle with a dense covering of hair-like spicules; a single oval anterior plate, about one quarter of the total length, occurs within the spicule mass (Vinther et al. 2017). In the holotype (Vinther et al. 2017, fig. 1) the anterior plate has a length of $5 \mathrm{~mm}$, compared to a length of about $1.2 \mathrm{~mm}$ in intermediate plates of the holotype of Qaleruaqia sodermanorum (Fig. 5B, C). The posterior plate in Halkieria evangelista (Fig. 7E, F) may exceed $12 \mathrm{~mm}$ in length, about one fifth of the overall length, but the anterior plate is only about two thirds of this (Conway Morris \& Peel 1995).

The single plate in Calvapilosa is closely similar to the head plates of Matthevia and Qaleruaqia with regard to its oval form, the anterior location of its apex and the tendency to develop a concave posterior train. Its shallow posterior sinus parallels the slight arching of the posterior margin seen in the two Cambrian forms. The plates of all three genera differ from the anterior plate of Halkieria, where the apex overhangs the posterior margin. It is not known if Matthevia and Qaleruaqia had spiculate girdles that can be compared to the dense thatch of Cavapilosa. However, spicules are characteristic of the Late Ordovician and Silurian aplacophorans Phthipodochiton Sutton \& Sigwart, 2012, Acaenoplax Sutton, Briggs, Siveter \& Siveter, 2001 and Kulindroplax. Matthevia is conventionally restored with eight plates (Vendrasco et al. 2009) compared to the single plate of Cavapilosa, although the exact number of plates is not known. Qaleruaqia developed anterior and intermediate plates (a posterior plate is not known) and probably had a similar number of plates to Matthevia.

Interpretation of Calvapilosa as an early aplacophoran would entail a significant loss of the series of dorsal plates usually located posterior to the head plate in palaeoloricates. Such a loss would stand in stark contrast to the interpretation of the single plate as a plesiomorphic character within aculiferans (Vinther et al. 2017), although 


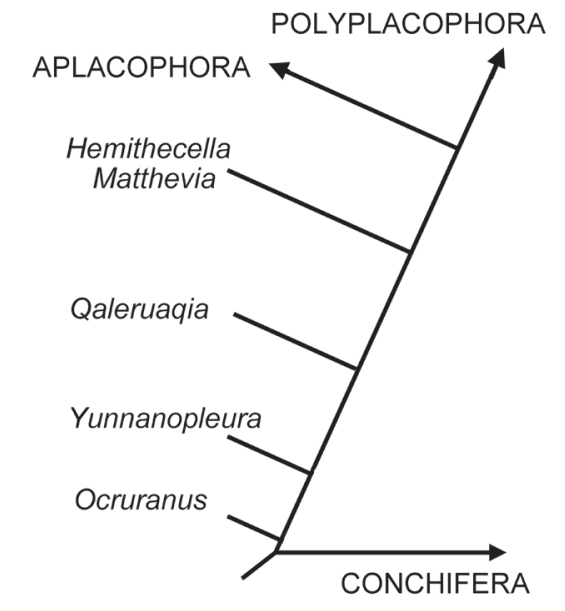

A

Figure 8. A - evolutionary relationship of Cambrian chiton-like stem group aculiferans. $-\mathrm{B}$ - time tree of aculiferan evolution, simplified after Vinther et al. (2017, fig. 4).

other contenders for this role in the earliest Cambrian (Yu 1987, Qian \& Bengtson 1989, Parkhaev \& Demidenko 2010) might be better placed than the Ordovician Calvapilosa. Absence of plates is a character of living aplacophorans, but the Ordovician and Silurian forms placed within Aplacophora by Sutton et al. (2012) retain seven or eight plates.

\section{Discussion}

Vendrasco et al. (2009) interpreted Ocruranus as a possible stem group chiton while acknowledging that the first undisputed chitons (i.e. Matthevia) occurred in the Furongian (Runnegar et al. 1979, Pojeta et al. 2010), although Sutton et al. (2012, fig. 2) placed Matthevia high in their Aplacophora clade. This oldest date is revised to Cambrian Series 2, Stage 4 following the description of Qaleruaqia sodermanorum. However, agreement is expressed with Vinther et al. (2012a) that the precise affinities of individual taxa as stem aculiferans, stem chitons or stem aplacophorans within the paraphyletic palaeoloricates are far from resolved. Molecular clock evidence cited by Vinther et al. (2012a) for the origin of aculiferans yielded a date of $488 \mathrm{Ma}$ (credibility interval 517-453 Ma). Kocot et al. (2020) suggested a slightly older date for aculiferan diversification (499 Ma) with a credibility interval of 479-520 Ma). Qaleruaqia sodermanorum dates from about $512 \mathrm{Ma}$ and the oldest Matthevia from about $490 \mathrm{Ma}$.

The micropolyplacophorans of $\mathrm{Yu}$ (1987) were regarded as probable stem group sachitids filling a gap between the earliest conchiferans and the appearance of the aculiferans by Vinther (2015), although Aculifera and Conchifera are regarded as sister groups by Vinther et al. (2017). Vinther et al. (2012a) noted that the absence of suitable intermediaries from Cambrian Series 1-3 was a problem for hypotheses that placed aplacophorans as a sister group to other molluscs (Haszprunar 1996, 2000; Salvini-Plawen 2006; Fig. 1B), although it may be countered that some members of the OcruranusEohalobia group could fill this gap. The absence of stem group chitons and aplacophorans before the Furongian supported their thesis that aplacophorans evolved from palaeoloricates in the Ordovician (Vinther et al. 2012a; Fig. 8B) but this aspect is weakened by the current

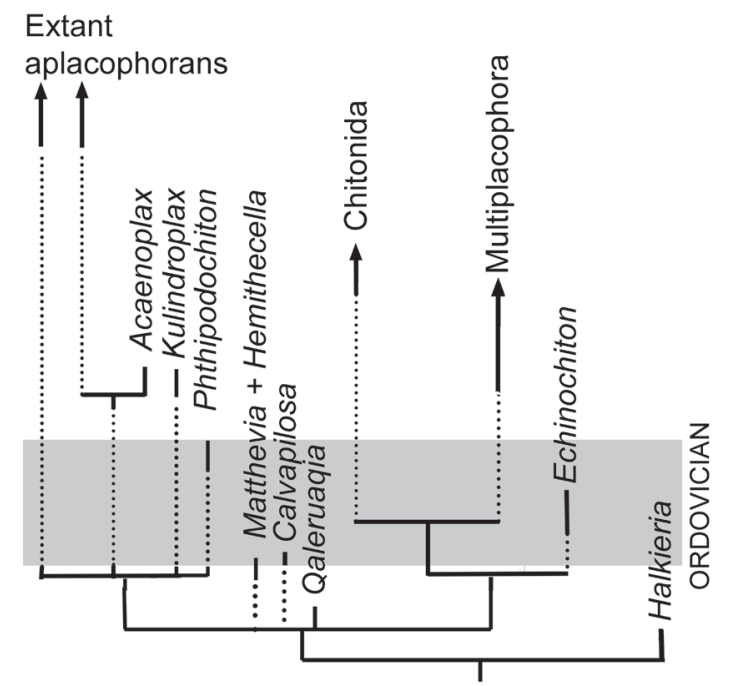

Figure 9. Time tree of aculiferan evolution modified after Vinther et al. (2017, fig. 4). 
description of Qaleruaqia sodermanorum from Cambrian Series 2 as regards its timing. Furthermore, the similarity between Chinese specimens of Yunnanopleura and intermediate plates of Qaleruaqia indicates an alternative (Fig. 8A) to the evolutionary pathway via Halkieria proposed by Vinther et al. (2012a, 2017).

Vinther et al. (2017) presented an analysis of ancestral molluscs that naturally focused on their accompanying description of the exceptionally preserved Calvapilosa kroegeri from the Early Ordovician of Morocco as a lower stem group aculiferan. In this model (Fig. 8B), the upper stem group aculiferan Halkieria is the sister group to Aculifera (Aplacophora and Polyplacophora, the latter including multiplacophorans). Their time tree, based on Bayesian total evidence analysis (Vinther et al. 2017, fig. 4), needs only slight modification following the description of Qaleruaqia sodermanorum. Matthevia was placed within the aplacophoran branch (Vinther et al. 2017, fig. 4), being regarded as an early crown or higher stem group aculiferan. Qaleruaqia sodermanorum could occupy a similar place to Matthevia, with the basal node of their clade Aplacophora thereafter being revised downwards from the Cambrian-Ordovician boundary interval to Cambrian Series 2. On account of its greater age and geological association with halkieriids (Hippopharangites), the description of Qaleruaqia sodermanorum strengthens the postulated derivation of aculiferans from a sachitid (Halkieria) root. There is, however, no convincing analysis of the distribution of most described palaeoloricate taxa between the aculiferan stem or the aplacophoran and polyplacophoran clades of Aculifera. Referral of Matthevia to the aplacophoran clade, as distinct from its traditional location in the polyplacophoran clade, is arbitrary. Pending such an analysis, Matthevia and Qaleruaqia are placed in the upper stem group (Fig. 9).

Given the focus of their study, it is perhaps not surprising that Vinther et al. (2017) placed the single plated Calvapilosa closer to the Aculifera-Conchifera basal node than Halkieria, although Calvapilosa occurs 30 Ma later in the geological record at a time when palaeoloricates are diversifying. The single shell of Calvapilosa more closely resembles the head plate of Matthevia and Qaleruaqia than that of Halkieria, suggesting that it might be placed together with these, with significant shell loss, rather than in the lower aculiferan stem (Fig. 9).

Zhao et al. (2017) placed Calvapilosa as an aculiferan but doubted its relationship to Halkieria, which they located together with tommotiids outside of Mollusca. They cited the lack of a radula in Halkieria as support for its supposed non-molluscan nature (Zhao et al. 2017), and presumably for its separation from Calvapilosa where a radula is clearly preserved (Vinther et al. 2017). Zhao et al. (2017) argued that a radula was not present in Halkieria because one is not preserved in material from the Sirius Passet Lagerstätte, while a radula is preserved in Wiwaxia from the Burgess Shale Lagerstätte and Calvapilosa from Fezouata Lagerstätte. This argumentation is rejected and seems to demonstrate a lack of awareness of both the complexity and variable nature of preservation at Sirius Passet (Strang et al. 2016a, b; Peel \& Ineson 2011a; Peel 2017; Hammarlund et al. 2019; Harper et al. 2019) where exceptional preservation was not afforded equally to all members of the biota. Individual taxa followed their own post mortem preservational pathways, some with preserved soft parts and some without. Shell-bearing Sirius Passetforms such as Halkieria evangelista, hyoliths and trilobites retain little information other than their articulated shells (Babcock \& Peel 2007, Peel 2010). The abundant trilobites almost never show traces of limbs, but often retain mineralised digestive glands (Babcock \& Peel 2007).

It is unfortunate that the elegant scheme of Vinther et al. (2017) lacks discussion of the Ocruranus-Eohalobia group of Vendrasco et al. (2009) as these earliest Cambrian problematic fossils may offer other pathways to and through the Aculifera (Fig. 8A). Also the problematic Cambrian Series 2 scleritome of Trachyplax Larsson, Peel \& Högström, 2009 is not mentioned despite several similarities with Silurian and younger multiplacophorans that are considered to be a branch of polyplacophorans (Vinther et al. 2017, fig. 4). While current restorations of its scleritome were not satisfying either to its authors (Larsson et al. 2009) or reviewers (Vinther et al. 2012b), the occurrence of Trachyplax in North Greenland in strata of the same age as Qaleruaqia urges circumspection.

\section{Acknowledgements}

Samples were collected during the North Greenland Project (1984-1985) of Grønlands Geologiske Undersøgelse, now a part of the Geological Survey of Denmark and Greenland (GEUS), Copenhagen, Denmark. Jan Ove R. Ebbestad and Anette E.S. Högström are thanked for reviewing the submitted manuscript.

\section{References}

Babcock, L.E. \& Peel, J.S. 2007. Palaeobiology, taphonomy, and stratigraphic significance of the trilobite Buenellus from the Sirius Passet Biota, Cambrian of North Greenland. Memoirs of the Association of Australasian Palaeontologists 34, 401-418.

Beedham, G.E. \& Trueman, E.R. 1967. The relationship of the mantle and shell of Polyplacophora in comparison with that of other Mollusca. Journal of Zoology 151, 215-231.

DOI 10.1111/j.1469-7998.1967.tb02875.x

Bengtson, S., Conway Morris, S., Cooper, B.J., Jell, P.A., \& 
RunNEGAR, B.N. 1990. Early Cambrian fossils from Australia. Memoir of the Australasian Association of Palaeontologists 9, 1-364.

Bergenhayn, J.R.M. 1955. Die fossilen Schwedischen loricaten nebst einer vorlaufi gen revision des systems der ganzen klasse Loricata. Lunds Universitets Arsskrift, Ny Följd 51, $3-43$.

Blainville, H.M.D. de 1816. Prodrome d'une nouvelle distribution Systematique du rene animal. Bulletin des Sciences, Philomathique de Paris 8, 105-124.

Budd, G.E. \& Jensen, S. 2007. A critical reappraisal of the fossil record of the bilaterian phyla. Biological Reviews 75, 253-295. DOI 10.1111/j.1469-185X.1999.tb00046.x

Caron, J.-B., Scheltema, A., Schander, C. \& Rudkin, D. 2006. A soft-bodied mollusc with radula from the Middle Cambrian Burgess Shale. Nature 442, 159-163. DOI 10.1038/nature04894

Checa, A.G., Vendrasco, M.J. \& Salas, C. 2017. Cuticle of Polyplacophora: structure, secretion, and homology with periostracum of conchiferans. Marine Biology 164(64), 1-17. DOI 10.1007/s00227-017-3100-6

Cherns, L. 1998a. Chelodes and closely related Polyplacophora (Mollusca) from the Silurian of Gotland, Sweden. Palaeontology 41, 545-573.

Cherns, L. 1998b. Silurian polyplacophoran molluscs from Gotland, Sweden. Palaeontology 41, 939-974.

Cherns, L. 2004. Early Palaeozoic diversification of chitons (Polyplacophora, Mollusca) based on new data from the Silurian of Gotland, Sweden. Lethaia 37, 445-456.

DOI 10.1080/00241160410002180

Conway Morris, S. \& Caron, J.B. 2007. Halwaxiids and the early evolution of the lophotrochozoans. Science 315 , 1255-1258. DOI 10.1126/science.1137187

Conway Morris, S. \& Peel, J.S. 1995. Articulated halkieriids from the Lower Cambrian of of North Greenland and their role in early protostome evolution. Philosophical Transactions of the Royal Society of London B 347 , 305-358. DOI 10.1098/rstb.1995.0029

Conway Morris, S., Peel, J.S., Higgins, A.K., Soper, N.J. \& DAvis, N.C. 1987. A Burgess Shale-like fauna from the Lower Cambrian of Greenland. Nature 326, 181-183.

DOI $10.1038 / 326181 \mathrm{a} 0$

Davidson, T. \& King, W. 1874. On the Trimerellidae, a Palaeozoic family of the palliobranchs or Brachiopoda. Quarterly Journal of the Geological Society London 30, 124-172. DOI 10.1144/GSL.JGS.1874.030.01-04.30

EIBYe-JACOBSEN, D. 2004. A reevaluation of Wiwaxia and the polychaetes of the Burgess Shale. Lethaia 37, 317-335. DOI 10.1080/00241160410002027

EngLish, A.M. 2002. The enigmatic mollusk Matthevia variabilis (Walcott, 1885): new insights regarding the morphology and systematic relationships of a probable Late Cambrian polyplacophoran. Northeastern Geology and Environmental Sciences 24, 293-297.
FonBlanque, A. 1837. England under seven administrations in three volumes, Vol. 3. 381 pp. Richard Bentley, London.

FrYKMAN, P. 1980. A sedimentological investigation of the carbonates at the base of the Brønlund Fjord Group (EarlyMiddle Cambrian), Peary Land, eastern North Greenland. Rapport Grønlands Geologiske Undersøgelse 99, 51-55.

Gravestock, D.I., Alexander, M.I., Demidenko, E.Yu., Esakova, N.V., Holmer, L.E., Jago, J.B., Melnikova, L.M., Parkhaev, P.Yu., Rozanov, A.Yu., Ushatinskaya, G.T., Zang, W., Zhegallo, E.A. \& Zhuravlev, A.Yu. 2001. The Cambrian biostratigraphy of the Stansbury Basin, South Australia. Russian Academy of Sciences Transactions of the Palaeontological Institute 282, 1-344.

Hammarlund, E.U., Smith, M.P., Rasmussen, J.A., Nielsen, A.T., Canfield, D.E. \& Harper, D.A.T. 2019. The Sirius Passet Lagerstätte of North Greenland - a geochemical window on early Cambrian low-oxygen environments and ecosystems. Geobiology 17, 12-26. DOI 10.1111/gbi.12315

Han, J., Conway Morris, S., Cuthill, J.F.H. \& Shu, D. 2019. Sclerite-bearing annelids from the lower Cambrian of South China. Scientific Reports 9, 4955. DOI 10.1038/s41598-019-40841-x

Harper, D.A.T., Hammarlund, E.U., Topper, T.P., Nielsen, A.T., Rasmussen, J.A., Park, T.S. \& Smith, M.P. 2019. The Sirius Passet Lagerstätte of North Greenland: a remote window on the Cambrian Explosion. Journal of the Geological Society 176, 1023-1037. DOI 10.1144/jgs2019-043

HaszPrunar, G. 1996. The Mollusca: coelomate turbellarians or mesenchymate annelids? 3-28. In TAYLOR, J.D (ed.) Origin and evolutionary radiation of the Mollusca. Oxford University Press, Oxford, UK.

Haszprunar, G. 2000. Is the Aplacophora monophyletic? A cladistic point of view. American Malacological Bulletin 15, 115-130.

HatscheK, B. 1891. Foreword in Blumrich, J. Das Integument der Chitonen. Zeitschrift für Wissenschaftliche Zoologie 52, 404- 476 .

Higgins, A.K., Ineson, J.R., Peel, J.S., Surlyk, F. \& Sønderholm, M. 1991. Lower Palaeozoic Franklinian Basin of North Greenland. Grønlands Geologiske Undersøgelse Bulletin 160, 71-139.

Hoare, R.D. 2000. Considerations on Paleozoic Polyplacophora including the description of Plasiochiton curiosus n. gen. and sp. American Malacological Bulletin 15, 131-137.

Hoare, R.D. 2009. Aesthete canals in the chiton Euleptichon spatulatus (Polyplacophora, Mollusca) from the Pennsylvanian of Ohio. Ohio Journal of Science 109, 48-51.

Hoare, R.D. \& Pojeta, J., JR 2006. Ordovician Polyplacophora (Mollusca) from North America. Paleontological Society Memoir 64, 1-27. DOI 10.1666/0022-3360(2006)80[1:OPMFNA]2.0.CO;2

Hollingsworth, J.S. 2011. Lithostratigraphy and biostratigraphy of Cambrian Stage 3 in western Nevada and eastern California. Museum of Northern Arizona, Bulletin 67, 26-42. 
Holmer, L.E., Skovsted, C.B. \& Williams, A. 2002. A stem group brachiopod from the lower Cambrian: support for a Micrina (halkieriid) ancestry. Palaeontology 45, 875-882. DOI 10.1111/1475-4983.00265

Hou, X., Siveter, D.J., Siveter, D.J., Aldridge, R.J., Cong, P., Gabbott, S.E., Ma, X., Purnell, M.A, \& Williams, M. 2017. The Cambrian Fossils of Chengjiang, China. The Flowering of Early Animal Life. Second edition. 316 pp. Wiley Blackwell, Chichester.

DOI 10.1002/9781118896372

Ineson, J.R. \& PeEL, J.S. 1997. Cambrian shelf stratigraphy of North Greenland. Geology of Greenland Survey Bulletin 173, $1-120$.

Ineson, J.R. \& Peel, J.S 2011. Geological and depositional setting of the Sirius Passet Lagerstätte (Early Cambrian), North Greenland. Canadian Journal of Earth Sciences 48, 1259-1281. DOI 10.1139/e11-018

Ineson, J.R., Surlyk, F., Higgins, A.K. \& Peel, J.S. 1994. Slope apron and deep shelf sediments of the Brønlund Fjord and Tavsens Iskappe Groups (Lower Cambrian-Lower Ordovician), North Greenland: stratigraphy, facies and depositional setting. Geology of Greenland Survey Bulletin 169, 7-24.

Ivanov, D.L. 1996. Origin of Aculifera and problems of monophyly of higher taxa in molluscs, 59-65. In TAYLOR, J.D (ed.) Origin and evolutionary radiation of the Mollusca. Oxford University Press, Oxford, UK.

JIANG, Z. 1980. Monoplacophorans and gastropods fauna of the Meishucun Stage from the Meishucun section, Yunnan. Acta Geologica Sinica 54, 112-123.

Kосот, K.M., PoustKa, A.J., Stöger, I., Halanych, K.M. \& SCHRÖDL, M. 2020. New data from Monoplacophora and a carefully curated dataset resolve molluscan relationships. Scientific Reports 10, art. 101. DOI 10.1038/s41598-019-56728-w

Косот, K.M., Todt, C., Mikkelsen, N.T. \& Halanych, K.M. 2019. Phylogenomics of Aplacophora (Mollusca, Aculifera) and a solenogaster without a foot. Proceedings of the Royal Society of London B 286, art. 20190115, 9 pp.

DOI 10.1098/rspb.2019.0115

Kouchinsky, A., Bengtson, S., Clausen, S. \& Vendrasco, M.J. 2015. An early Cambrian fauna of skeletal fossils from the Emyaksin Formation, northern Siberia. Acta Palaeontologica Polonica 60, 421-512.

Kouchinsky, A., Bengtson, S., Landing, E., Steiner, M., Vendrasco, M. \& Ziegler, K. 2017. Terreneuvian stratigraphy and faunas from the Anabar uplift, Siberia. Acta Palaeontologica Polonica 62, 311-340.

DOI 10.4202/app.00289.2016

Larsson, C., Peel J.S. \& Högström, A.E.S. 2009. Trachyplax arctica, a new multiplated problematic fossil from the lower Cambrian of North Greenland. Acta Palaeontologica Polonica 54, 513-523. DOI 10.4202/app.2009.0026

LinNaeus, C. 1758. Systema naturce per regna tria naturce, secundum classes, ordines, genera, species, cum characteribus, differentiis, synonymis, locis. Vol. 1 (10 th edition). 824 pp. Laurentius Salvius, Stockholm.

DOI 10.5962/bhl.title.542

Liu, D.-Y. 1979. Earliest Cambrian brachiopods from southwest China. Acta Palaeontologica Sinica 18, 505-512. [in Chinese with English summary]

Maloof, A.C., Porter, S.M., Moore, J.L., Dudas, F.O., Bowring, S.A., Higgins, J.A., Fike, D.A. \& Eddy, M.P. 2010. The earliest Cambrian record of animals and ocean geochemical change. Geological Society of America Bulletin 122, 1731-1774. DOI 10.1130/B30346.1

Missarzhevsky, V.V. 1974. New data on the oldest fossils of the Early Cambrian of the Siberian Platform, 179-189. In Zhuravleva, I.T. \& Rozanov, A.Yu (eds) Biostratigrafiâ i paleontologiâ nižnego kembriâ Evropii i severnoi Azii. Nauka, Novosibirsk. [in Russian]

Missarzhevsky, V.V. 1989. Oldest skeletal fossils and stratigraphy of Precambrian and Cambrian boundary beds. Trudy Geologičeskogo Instituta, Akademiâ Nauk SSSR 443, 1-237. [in Russian]

PARKhAEV, P.Yu. 2008. The early Cambrian radiation of Mollusca, 33-69. In Ponder, W.F. \& Lindberg, D.R. (eds) Phylogeny and evolution of the Mollusca. University of California Press, Berkeley. DOI 10.1525/california/9780520250925.003.0003

PARKhaEv, P.Yu. 2019. Cambrian molluscs of Australia: overview of taxonomy, biostratigraphy and paleobiogeography. Stratigrafiya, Geologicheskaya Korrelatsiya 27, 52-79. DOI 10.31857/S0869-592X27252-79

Parkhaev, P.Yu. \& Demidenko, Yu.E. 2010. Zooproblematica and Mollusca from the Lower Cambrian Meishucun Section (Yunnan, China), and taxonomy and systematicsof the Cambrian small shelly fossils of China. Paleontological Journal 44, 883-1161. DOI 10.1134/S0031030110080010

Peel, J.S. 1991a. The Classes Tergomya and Helcionelloidea, and early molluscan evolution. Bulletin Grønlands Geologiske Undersøgelse 161, 11-65.

Peel, J.S. 1991b. Introduction. Articulated halkieriids and microchitons. Bulletin Grønlands Geologiske Undersøgelse $161,5-10$.

Peel, J.S. 2010. Articulated hyoliths and other fossils from the Sirius Passet Lagerstätte (early Cambrian), North Greenland. Bulletin of Geosciences 85, 385-394. DOI 10.3140/bull.geosci. 1207

PeEL, J.S. 2017. The oldest pelmatozoan encrusted hardground and holdfasts from Laurentia (Cambrian Series 2-3). GFF 139, 195-204. DOI 10.1080/11035897.2017.1347196

Peel, J.S. 2019. Tarimspira from the Cambrian (Series 2, Stage 4) of Laurentia (Greenland): extending the skeletal record of paraconodontid vertebrates. Journal of Paleontology 93, 115-125. DOI 10.1017/jpa.2018.68

Peel, J.S. \& Ineson, J.R. 2011a. The Sirius Passet Lagerstätte (early Cambrian) of North Greenland. Palaeontographica Canadiana 31, 109-118. 
Peel, J.S. \& Ineson, J.R. 2011b. The extent of the Sirius Passet Lagerstätte (early Cambrian) of North Greenland. Bulletin of Geoscience 86, 535-543. DOI 10.3140/bull.geosci.1269

Peel, J.S. \& Willman, S. 2018. The Buen Formation (Cambrian Series 2) biota of North Greenland. Papers in Palaeontology 4, 381-432. DOI 10.1002/spp2.1112

Pojeta, J., JR \& DuFoe, J. 2008. New information about Echinochiton dufoei, the Ordovician spiny chiton. American Malacological Bulletin 25, 25-34.

DOI 10.4003/0740-2783-25.1.25

Pojeta, J., JR \& Runnegar, B. 1976. The paleontology of rostroconch mollusks and the early history of the phylum Mollusca. United States Geological Survey Professional Paper 968, 1-88. DOI /10.3133/PP968

Pojeta, J., JR, Taylor, J.H. \& Darrough, G. 2005. Matthevia (Polyplacophora) invades the Ordovician: the first reported post-Cambrian occurrence. Journal of Paleontology 79, 1021-1027. DOI 10.1666/0022-3360(2005)079[1021:MPITOT]2.0.CO;2

Pojeta, J., Jr, Vendrasco, M.J. \& Darrough, G. 2010. Upper Cambrian chitons (Mollusca, Polyplacophora) from Missouri, USA. Bulletins of American Paleontology 379, 1-82.

Pojeta, J., Jr, Eernisse, D.J., Hoare, R.D. \& Henderson, M.D. 2003. Echinochiton dufoei: a new spiny Ordovician chiton. Journal of Paleontology 77, 646-654.

DOI 10.1666/0022-3360(2003)077<0646:EDANSO>2.0.CO;2

QIAN, Y. 1977. Hyolitha and some problematica from the Lower Cambrian Meisuchun Stage in central and SW China. Acta Palaeontologica Sinica 16, 255-278. [in Chinese with English summary]

Qian, Y. \& Bengtson, S. 1989. Palaeontology and biostratigraphy of the Early Cambrian Meisuchunian Stage in Yunnan Province, South China. Fossils and Strata 24, 1-156.

Rolfe, W.D.I. 1981. Septemchiton - a misnomer. Journal of Paleontology 55, 675-678.

Rozanov, A.Yu., Parkhaev, P.Yu., Demidenko, Yu.E., Karlova, G.A., Korovnikov, I.V., Shabanov, Yu.Ya, Ivantsov, A.Yu., Luchinina, V.A., MalakhovsKaya, Ya.E., Melnikova, L.M., Naimark, E.B., Ponomarenko, A.G., Skorlotova, N.A., Sundukov, V.M., Tokarev, D.A., Ushatinskaya, G.T. \& Kipriyznova, L.D. 2010. Fossils from the Lower Cambrian Stage Stratotypes. 228 pp. Russian Academy of Sciences Transactions of the Palaeontological Institute, Moscow. [in Russian]

Runnegar, B. \& PoJeta, J., JR 1974. Molluscan phylogeny: the paleontological viewpoint. Science 186, 311-317.

DOI 10.1126/science.186.4161.311

RunNegar, B. \& PoJeta, J., JR 1985. Origin and diversification of the Mollusca, 1-57. In Trueman, E.R. \& Clarke, M.R. (eds) The Mollusca 10, Evolution. Academic Press, Orlando. DOI 10.1016/B978-0-12-751410-9.50009-5

Runnegar, B., Pojeta, J. JR, Taylor, M.E. \& Collins, D. 1979. New species of the Cambrian and Ordovician chitons Matthevia and Chelodes from Wisconsin and Queensland: evidence for the early history of polyplacophoran mollusks. Journal of Paleontology 53, 1374-1394.

Salvini-Plawen, L. von 2006. The significance of the Placophora for molluscan phylogeny. Venus $65,1-17$.

Scheltema, A.H. \& Ivanov, D.L. 2002. An aplacophoran postlarva with iterated dorsal groups of spicules and skeletal similarities to Paleozoic fossils. Invertebrate Biology 121, 1-10. DOI 10.1111/j.1744-7410.2002.tb00124.x

Scherholz, M., Redl, E., Wolleson, T., Todt, C. \& Wanninger, A. 2013. Aplacophoran mollusks evolved from ancestors with polyplacophoran-like features. Current Biology 23, 2130-2134.

Schwabe, E. 2010. Illustrated summary of chiton terminology. Spixiana 33, 171-194.

Sigwart, J.D. \& Sutton, M.D. 2007. Deep molluscan phylogeny: synthesis of palaeontological and neontological data. Proceedings of the Royal Society of London B 274, 2413-2419. DOI 10.1098/rspb.2007.0701

Sigwart, J.D., VermeiJ, G.J. \& Hoyer, P. 2019. Why do chitons curl into a ball? Biology Letters 15, art. 20190429. DOI 10.1098/rsbl.2019.0429

Smith, A.G. 1960. Amphineura, I41-I76. In Moore, R.C. (ed.) Treatise on Invertebrate Paleontology Part I, Mollusca 1. Geological Society of America and University of Kansas Press, Lawrence, Kansas.

Smith, A.G. \& Hoare, R.D. 1987. Paleozoic Polyplacophora: a checklist and bibliography. Occasional papers of the California Academy of Sciences 146, 1-71.

Steiner, M., Li, G., Qian, Y., Zhu, M. \& Erdtmann. B.-D. 2007. Neoproterozoic to early Cambrian small shelly fossil assemblages and a revised biostratigraphic correlation of the Yangtze Platform (China). Palaeogeography, Palaeoclimatology, Palaeoecology 254, 67-99.

DOI 10.1016/j.palaeo.2007.03.046

Stinchсомb, B.L. \& Darrough, G. 1995. Some molluscan Problematica from the Upper Cambrian-Lower Ordovician of the Ozark uplift. Journal of Paleontology 69, 52-65. DOI 10.1017/S0022336000026913

Stockfors, M. \& Peel, J.S. 2005a. Endolithic Cyanobacteria from the Middle Cambrian of North Greenland. GFF 127, 179-185. DOI 10.1080/11035890501273179

Stockfors, M. \& Peel, J.S. 2005b. Euendoliths and cryptoendoliths within late Middle Cambrian brachiopod shells from North Greenland. GFF 127, 187-194.

DOI 10.1080/11035890501273187

Strang, K.M., Armstrong, H.A. \& Harper, D.A.T. 2016 a. Minerals in the gut: scoping a Cambrian digestive system. Royal Society Open Science 3, art. 160420, 9 pp. DOI 10.1098/rsos.160420

Strang, K.M., Armstrong, H.A., Harper, D.A.T. \& TrabuchoAlexandre, J.P. 2016b. The Sirius Passet Lagerstätte: silica death masking opens the window on the earliest mat ground community of the Cambrian explosion. Lethaia 49, 631-643. DOI 10.1111/let.12174 
Sutton, M.D. \& Sigwart, J.D. 2012. A chiton without a foot. Palaeontology 55, 401-411. DOI 10.1111/j.1475-4983.2011.01126.x

Sutton, M.D., Briggs, D.E.G., Siveter, D.J. \& Siveter, D.J. 2001. An exceptionally preserved vermiform mollusc from the Silurian of England. Nature 410, 461-463.

DOI 10.1038/35068549

Sutton, M.D., Briggs, D.E.G., Siveter, D.J. \& Siveter, D.J. 2004. Computer reconstruction and analysis of the vermiform mollusc Acaenoplax hayae from the Herefordshire Lagerstatte (Silurian, England), and implications for molluscan phylogeny. Palaeontology 47, 293-318.

DOI 10.1111/j.0031-0239.2004.00374.x

Sutton, M.D., Briggs, D.E.G., Siveter, D.J., Siveter, D.J. \& SigWART, J.D. 2012. A Silurian armoured aplacophoran and implications for molluscan phylogeny. Nature 490, 94-97. DOI 10.1038/nature11328

Todt, C., Okusu, A. Schander, C. \& Schwabe, E. 2008. Solenogastres, Caudofoveata and Polyplacophora, 71-96. In PONDER, W.F. \& Lindberg, D.R. (eds) Phylogeny and evolution of the Mollusca. University of California Press, Berkeley. DOI 10.1525/california/9780520250925.003.0004

Ulrich, E.O. \& Bridge, J. 1941. Hemithecella expansa, 19-20. In Butts, C. (ed.) Geology of the Appalachian Valley in Virginia, Pt. 2. Virginia Geological Survey Bulletin 52.

Vendrasco, M.J. \& Runnegar, B. 2004. Late Cambrian and Early Ordovician stem group chitons (Mollusca: Polyplacophora) from Utah and Missouri. Journal of Paleontology 78, 675-689. DOI 10.1666/0022-3360(2004)078<0675:LCAEOS >2.0.CO;2

Vendrasco, M.J., Li, G., Porter, S.M. \& Fernandez, C.Z. 2009. New data on the enigmatic Ocruranus - Eohalobia group of early Cambrian small skeletal fossils. Palaeontology 52, 1373-1396. DOI 10.1111/j.1475-4983.2009.00913.x

VINTHER, J. 2014. A molecular palaeobiological perspective on aculiferan evolution. Journal of Natural History 48, 2805-2823. DOI 10.1080/00222933.2014.963185

Vinther, J. 2015. The origins of molluscs. Palaeontology 58, 19-34. DOI 10.1111/pala.12140

Vinther, J. \& Nielsen, C. 2005. The Early Cambrian Halkieria is a mollusc. Zoologica Scripta 34, 81-89. DOI 10.1111/j.1463-6409.2005.00177.x

Vinther, J., Jell, P., Kampouris, G., Carney, R., Racicot, R. \& Briggs, D.E.G. 2012b. The origin of multiplacophorans convergent evolution in aculiferan molluscs. Palaeontology 55, 1007-1019. DOI 10.1111/j.1475-4983.2012.01180.x
Vinther, J., Parry, L., Briggs, D.E.G. \& Van Roy, P. 2017. Ancestral morphology of crown-group molluscs revealed by a new Ordovician stem aculiferan. Nature 542, 471-474. DOI 10.1038/nature21055

Vinther, J., Sperling, E.A., Briggs, D.E.G. \& Peterson, J. 2012 a. A molecular palaeobiological hypothesis for the origin of aplacophoran molluscs and their derivation from chiton-like ancestors. Proceedings of the Royal Society of London B 279, 1259-1268. DOI 10.1098/rspb.2011.1773

Voronin, Y.I., Voronova, L.G., Grigorieva, N.V., Drozdova, N.A., Zhegallo, E.A., Zhuravlev, A.Yu., Ragozina, A.L., Rozanov, A.Yu., Sayutina, T.A., Sysoev, V.A. \& Fonin, V.D. 1982. The Precambrian-Cambrian boundary in the geosynclinal regions (reference section Salany-Gol, MNR). Trudy Sovmestnoj sovetsko-mongolskoj paleontologicheskoj ekspedicii 18, 1-150. [in Russian]

Walcott, C.D. 1885. Note on some Paleozoic pteropods. American Journal of Science 30, 17-21.

DOI 10.2475/ajs.s3-30.175.17

Walcott, C.D. 1886. Second contribution to the studies of the Cambrian faunas of North America. U.S. Geological Survey Bulletin 30, 1-369. DOI 10.5962/bhl.title.38399

Wanninger, A. \& Wollesen, T. 2019. The evolution of molluscs. Biological Reviews 94, 102-105. DOI 10.1111/brv.12439

Yochelson, E.L. 1966. Mattheva, a proposed new class of mollusks. United States Geological Survey Professional Paper 523B, 11 pp. DOI 10.3133/pp523B

Yochelson, E.L. 1978. An alternative approach to the interpretation of the phylogeny of ancient mollusks. Malacologia 17, 165-191.

YU, W. 1987. Yangtze micromolluscan fauna in Yangtze region of China with notes on the Precambrian-Cambrian boundary. Stratigraphy and paleontology of systematic boundaries in China. Precambrian-Cambrian boundary (part 1), 19-344 pp. Nanjing University Publishing House, Nanjing.

Yu, W. 2001. The earliest Cambrian polyplacophorans from China. Records of the Western Australian Museum 20, 167-185.

Yu, W. 2014. On the Yangtzeconus Priscus-Archaeospira Ornata Assemblage (Mollusca) of the Earliest Cambrian of China. Acta Geologica Sinica 88, 1262-1287. DOI 10.1111/1755-6724.12288

Zhao, F., Smith, M.R., Yin, Z., Zeng, H. Li, G. \& Zhu, M. 2017. Orthrozanculus elongata $\mathrm{n}$. sp. and the significance of sclerite-covered taxa for early trochozoan evolution. Scientific Reports 7, art. 16232. DOI 10.1038/s41598-017-16304- 